\title{
THE FEMINIST CRITIQUE OF LIBERALISM
}

by

MARTHA C. NUSSBAUM

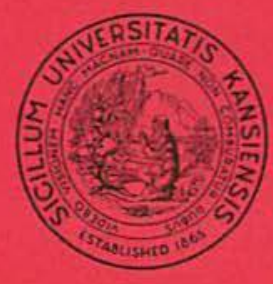

The Lindley Lecture

The University of Kansas

1997 
The E. H. Lindley Memorial Lectureship Fund was established in 1941 in memory of Ernest H. Lindley, Chancellor of the University of Kansas from 1920 to 1939. In February 1941 Mr. Roy Roberts, the chairman of the committee in charge, suggested in the Graduate Magazime that

the Chancellor should invite to the University for a lecture or a series of lectures, some outstanding national or world figure to speak on "Values of Living"-just as the late Chancellor proposed to do in his courses "The Human Situation" and "Plan for Living."

In the following June Mr. Roberts circulated a letter on behalf of the Committee, proposing in somewhat broader terms that

The income from this fund should be spent in a quest of social betterment by bringing to the University each year outstanding world leaders for a lecture or series of lectures, yet with a design so broad in its outline that in the years to come, if it is deemed wise, this living memorial could take some more desirable form.

The fund was allowed to accumulate until 1954, when Professor Richard McKeon lectured on "Human Rights and International Relations." The next lecture was given in 1959 by Professor Everett C. Hughes, and has been published by the University of Kansas School of Law as part of his book Students ' Culture and Perspectives: Lectures on Medical and General Education. The selection of lecturers for the Lindley series has since been delegated to the Department of Philosophy.

$$
* * *
$$

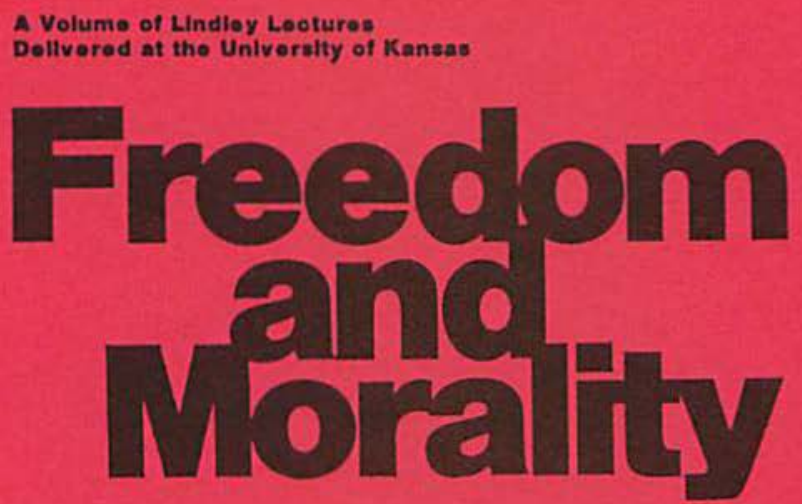

Alohard B. Brandt Morar Prolowobhy and the
Andiveis of Language

Boderlok M. Chiaholm himan firbogm and ov Se? Stuart Hampahire Firosis of und

William K. Frankena forr belis about jusice

wiltrid solters

rom and Content in Eincal

Theoly
J. N. Findiay The 5rsteroatic uritr of value

Alan Qewirth Mord Fatorats,

Albert Molstadtor Halloctore on Ent

Paul Rlcoeur hrat is Dateclsa?

ค. M. Hare Sorve contuons about sucactivit

Eaind win an erroovicton or John Ericko
The volume can be purchased for $\$ 6.00$ from the Library Sales Office, University of Kansas Libraries, Lawrence, Kansas (U.S.A.) 66045. Please include a $50^{\circ}$ handing tee, $75^{\circ}$ outside the United States. 


\section{THE FEMINIST CRITIQUE OF LIBERALISM}

by

MARTHA C. NUSSBAUM

Ernst Freund Professor of Law and Ethics

University of Chicago

The Lindley Lecture, University of Kansas

March 4, 1997 
() Copyright 1997 by Department of Philosophy

University of Kansas 


\title{
The Feminist Critique of Liberalism
}

\author{
Martha C. Nussbaum*
}

Women around the world are using the language of liberalism. Consider some representative examples from recent publications:

1. Roop Rekha Verma, philosopher and grass-roots activist from Lucknow, India, speaks about the many ways in which Indian religious traditions have devalued women. She concludes that the largest problem with these traditions is that they deprive women of "full personhood." "What is personhood?" Verma asks. "To me three things seem essential for [full personhood]: autonomy, self-respect, and a sense of fulfillment and achievement."

2. Nahid Toubia, the first woman surgeon in the Sudan and woman's health activist, writes of the urgent need need to mobilize international opposition to the practice of female genital mutilation, especially when it is performed on young girls without their consent. "International human rights bodies and organizations," she concludes, " must declare FGM to be violence against women and children and a violation of their rights... If women are to be considered as equal and responsible members of society, no aspect of their physical, psychological, or sexual integrity can be compromised."2

3. Describing a meeting at the Indian Institute of Management in Bangalore that brought together widows from all over India for a discussion of their living conditions, The Hindu Magazine reports as follows:

Throughout the week they came to realise many things about themselves and their lives-especially how much they had

\footnotetext{
* Ernst Freund Professor of Law and Ethics: Law School, Philosophy Department, and Divinity School, The University of Chicago. I am extremely grateful to Al Alschuler, Ruth Chang, Richard De Liberty, Kenneth Dover, David Estlund, Gertrud Fremling, Elizabeth Garrett, Stephen Holmes, Dan M. Kahan, Jeremy Bendik Keymer, Tracey Meares, Richard Posner, Mark Ramseyer, Kaspar Stoffelmayr, David Strauss, Cass Sunstein, and Candace Vogler for their very helpful comments on an earlier draft, and to Ross Davies for research assistance. I dedicate this essay to the memory of Jean Hampton, the outstanding moral philosopher and feminist thinker who died tragically of a stroke in March 1996 at the age of forty. Jean defended a form of feminism grounded in the liberal tradition, in articles such as "Feminist Contractarianism," in A Mind of One's Oum: Feminist Essays on Reason and Objectivity, ed. L. Antony and C. Witt (Boulder: Westriew, 1993), and "The Case for Feminism," in The Liberation Debate: Rights at Jssue, ed. M. Leahy and D. Cohn-Sherbok (London: Routledge, 1996). She was a wonderful person. I hope this essay provides a useful continuation of her work.
} 
internalised society's perceptions of them as daughters, wives, mothers and widows (their identity invariably defined in terms of their relationship to men).... They were encouraged to see themselves as persons who had a right to exist even if their husbands were dead, and as citizens who had a right to resourcessuch as land, housing, employment, credit and ration cards- which would enable them to live and bring up their children (if any) with dignity and self-respect. ${ }^{3}$

Personhood, autonomy, rights, dignity, self-respect: these are the terms of the liberal Enlightenment. Women are using them, and teaching other women to use them when they did not use them before. They treat these terms as though they matter, as though they are the best terms in which to conduct a radical critique of society, as though using them is crucial to women's quality of life.

This situation looks in some respects deeply paradoxical, since liberalism has been thought by many feminists to be a political approach that is totally inadequate to the needs and aims of women, and in some ways profoundly subversive of those aims. Over the past twenty years feminist political thinkers have put forward many reasons to reject liberalism and to define feminism to some extent in opposition to liberalism. In 1983, in one of the most influential works of feminist political theory, Alison Jaggar concluded that "the liberal conception of human nature and of political philosophy cannot constitute the philosophical foundation for an adequate theory of women's liberation. ${ }^{\text {"4 }}$ Many influential feminist thinkers have tended to agree with Jaggar, and to treat liberalism as at best negligent of women's concerns and at worst an active enemy of women's progress.

But liberalism has not died in feminist politics; if anything, with the dramatic growth of the movement to recognize various women's rights as central human rights under international law, its radical feminist potential is just beginning to be realized. So it is time to reassess the charges most commonly made in the feminist critique of liberalism to see whether they really give us good reasons to view the continued ascendancy of feminist liberalism with skepticism.

Who is this "us", and why should "our" conclusions matter? It is obvious that the activists from whom I have quoted have gone about their business undaunted by the feminist critique, and they will not be daunted now, if feminists once again tell them that autonomy and personhood are bad notions for feminists to use. In that sense a philosophical reassessment could be seen as beside the point. But the international political situation is volatile, and the liberal discourse of 
personhood and rights has come under attack from many directions, some of them practical and influential. ${ }^{5}$ Looking at the case for the defense is therefore not simply a scholarly exercise, but also a contribution to practical politics.

I shall examine the feminist critique under three headings: (1) Individualism and Community; (2) Abstraction and Concrete Reality; (3) Reason and Emotion. In general, I shall argue, liberalism of a kind can be defended against the charges that have been made. The deepest and most central ideas of the liberal tradition are ideas of radical force and great theoretical and practical value. These ideas can be formulated in ways that incorporate what is most valuable in the feminist critique-although liberalism needs to learn from feminism if it is to formulate its own central insights in a fully adequate manner. Taking on board the insights of feminism will not leave liberalism unchanged, and liberalism needs to change to respond adequately to those insights: but it will be changed in ways that make it more deeply consistent with its own most foundational icleas. Another way of expressing this point is to say that there have been many varieties of liberalism and many strands within liberalism; thinking about the feminist critique proves important in choosing among these varieties, because feminism does show real weaknesses in some forms of liberalism that continue to be influential, though not, I shall argue, in the most basic ideas of liberalism itself. Some feminist proposals do resist incorporation even into a reformulated feminist liberalism; but I shall argue that these are proposals that should be resisted, as we attempt to promote justice for the world's women.

There is danger in speaking so generally about "liberalism," a danger that has often plagued feminist debates. "Liberalism" is not a single position, but a family of positions; it is obvious that Kantian liberalism is profoundly different from classical utilitarian liberalism, and both of these from the utilitarianism currently dominant in neoclassical economics. Many critiques of liberalism are really critiques of economic utilitarianism, and would not hold against the views of Kant, or Mill. Some feminist attacks oversimplify the tradition, and in responding to them I run a grave risk of oversimplification myself. When I speak of "liberalism," then, I shall have in mind, above all, the tradition of Kantian liberalism represented today in the political thought of John Rawls, and also the classical utilitarian liberal tradition, especially as exemplified in the work of John Stuart Mill. I shall also refer frequently to some major precursors, namely Rousseau, Hume, and Adam Strtith, who made enormously important contri- 
butions to the development of liberal ideas of equality and choice. It seems reasonable to assess the feminist critique by holding it up against the best examples of liberal political thought; any critique of liberalism that can't be taken seriously as a criticism of Kant or Mill probably is not worth discussing.

The thinkers I have chosen are not in agreement on many important matters; but there is a core of common commitments that can be scrutinized with the interests of feminism in mind. At the heart of this tradition is a twofold intuition about human beings: namely, that all, just by being human, are of equal dignity and worth, no matter where they are situated in society; and that the primary source of this worth is a power of moral choice within them, a power that consists in the ability to plan a life in accordance with one's own evaluations of ends. ${ }^{6}$ To these two intuitions-which link liberalism at its core to the thought of the Greek and Roman Stoics ${ }^{7}$ - the liberal tradition adds one more, which the Stoics did not emphasize: that the moral equality of persons gives them a fair claim to certain types of treatment at the hands of society and politics. What this treatment is will be a subject of debate within the tradition, but the shared starting point is that this treatment must do two closely related things. It must respect and promote the liberty of choice, and it must repect and promote the equal worth of persons as choosers. ${ }^{8}$

To what is liberalism, so conceived, opposed? Here again we must begin crudely, with some rough intuitions that we will try to render more precise as we go on. Liberalism is opposed, first of all, to any approach to politics that turns morally irrelevant differences into systematic sources of social hierarchy. ${ }^{9}$ It is opposed, then, to the naturalizing of hierarchies - to the caste system characteristic of traditional Indian society; to related caste hierarchies created in many times and places by differences of race and class and power and religion. ${ }^{10}$ It is opposed, second, to forms of political organization that are corporatist or organically organized-that seek a good for the group as a whole without focusing above all on the well-being and agency of individual group members. " Finally, it is opposed to a politics that is ideologically based, in the sense that it turns one particular conception of value-whether utopian or religious or traditional-into a mandatory standard imposed by authority on all citizens. Religious intolerance, the establishment of a single church, or the establishment of a single utopian political vision of the good-all of these strike the liberal as embodying unequal respect for persons, who ought to be free to follow their conscience in the most important matters. Liberalism is thus 
opposed to Marxism, to theocratic social orders, and to many forms of authoritarian or tradition-based conservatism. ${ }^{12}$

Liberalism so conceived is centrally about the protection of spheres of choice-not, I claim, in a purely negative way, maximizing the sheer number of choices people get to make for themselves, but rather in a way closely tied to the norm of equal respect for personhood. The choices that get protection will be those deemed to be of crucial importance to the protection and expression of personhood. Thus it would be perfectly consistent for a liberal, beginning from these intuitions, to support certain forms of interference with choice if it could be successfully argued that such interference promotes equal respect rather than undermining it, or, even, that the interference makes no difference to personhood one way or another. All liberal views accept some interference with choice, whether to promote more choice, or to constrain force and fraud, or to produce greater overall prosperity, or greater fairness. Starting from the same basic intuitions, then, liberals can end up in very different positions about many matters, such as the justice of various types of economic redistribution, or the appropriateness of various types of paternalistic legislation. They will differ about these policies because they differ about what is crucial in order to respect the equal worth of persons and to give the power of choice the support that is its due. On this account, both John Rawls and Robert Nozick are liberals, because both share a central commitment to liberty and equal respect, although they disagree profoundly about the permissibility of economic redistribution-Rawls holding that it is required in order to show equal respect for persons, Nozick holding that it is incompatible with such equal respect. ${ }^{13}$ Many such disagreements arise within liberalism. They involve, often, not only disagreement about means to shared ends, but also different concrete specifications of some highly gencral ends. ${ }^{14}$ On the other hand, it would be hard to conceive of a form of liberalism in which religious toleration was not a central tenet, or one that did not protect certain basic freedoms associated with personal choice, such as freedoms of expression, press, and assembly. ${ }^{15}$

Feminists have made three salient charges against this liberal tradition as a philosophy that might be used to promote women's goals. They have charged, first, that it is too "individualistic": that its focus on the dignity and worth of the individual slights and unfairly subordinates the value to be attached to community and to collective social entities such as families, groups, and classes. They have charged, second, that its ideal of equality is too abstract and formal, that it errs 
through lack of immersion in the concrete realities of power in different social situations. Finally, they have charged that liberalism errs through its focus on reason, unfairly slighting the role we should give to emotion and care in the moral and political life. All these alleged failings in liberalism are linked to with specific failings in the tradition's handling of women's issues. It has frequently been claimed that liberalism cannot atone for these defects without changing utterly, and that feminists interested in progress beyond the status quo would be better off choosing a different political philosophy-whether a form of socialism or Marxism, or a form of communitarian or care-based political theory. Let us examine these charges.

\section{Individual and Community}

The most common feminist charge against liberalism is that it is too "individualistic." By taking the individual to be the basic unit for political thought, it treats the individual as prior to society, as capable, in theory if not in fact, of existing outside of all social ties. "Logically if not empirically," writes Jaggar of the liberal view, "human individuals could exist outside a social context; their essential characteristics, their needs and interests, their capacities and desires, are given independently of their social context and are not created or even fundamentally altered by that context." ${ }^{16}$ Jaggar later restates this liberal "metaphysical assumption" in an even stronger form: "each human individual has desires, interests, etc. that in principle can be fulfilled quite separately from the desires and interests of other people." 17 Jaggar later describes this as the liberal assumption of "political solipsism, the assumption that human individuals are essentially self-sufficient entities." ${ }^{\text {18 }}$ She holds that this starting point makes liberals characterize "community and cooperation...as phenomena whose existence and even possibility is puzzling," if not downright "impossible."19

Described this way, liberal individualism lies perilously close to two positions most feminists agree in rejecting: egoism and normative selfsufficiency. If liberals really did hold, as Jaggar suggests, that the most basic desires of human beings are not only not shaped by society but also are desires that can be satisfied independently of the satisfactions of desires and interests of others, they would indeed be close to endorsing psychological egoism, the view that people are all motivated to pursue their own self-interest above all else. And this, of course, is a view that makes cooperation and community at least somewhat puz- 
zling. On the basis of Jaggar's belief that such self-centered desires and interests are given special weight in liberal politics, she apparently takes the liberal view to lic close to normative ethical egoism as well, ${ }^{21}$ that is, to a view that it is always best to promote the satisfaction of one's own self-interest-though such a conclusion is rather puzzling given that the political theories she discusses, both Utilitarian and Rawlsian, aim, by Jaggar's own account, at satisfying everyone's interests, not just the interests of a single agent. This would seem to make them far from egoistic."1

The charge of egoism is unconvincing. Some liberal thinkers do assume a form of psychological egoism, and it is right of both feminists and others to call that assumption into question. Jaggar cites Amartya Sen's article "Rational Fools, ${ }^{22}$ which criticizes economic utilitarianism for underrating the importance of sympathy and commitment as motives; she is right to find this a powerful objection to some dominant modes of economic modeling. But she herself admits that this view of human motivation is far from universal in the liberal tradition: that John Rawls has a non-egoistic account of human psychology, and that Mill and Kant think of the human being as moved by both egoistic and non-egoistic motives. ${ }^{23}$ She does not give us any reason to believe that the egoism she criticizes in economic utilitarianism is entailed or even encouraged by anything deep in liberalism itself.

Indeed, even Jaggar's weaker psychological claim about the solitary character of basic desires in liberalism appears to be inaccurate. Liberal theorists vary, and no doubt some, in particular Hobbes ${ }^{24}$ and Bentham in their different ways, come close to imagining the human individual as having no natural love of others. Kant, because he holds that all sensuous inclinations are accidents of individual endowment, is agnostic on the matter, and thinks that we should not rely on such motives too much if we want to promote benevolence. But other liberal thinkers, such as Mill, Hume, Smith, and Rawls, have an evidently social and other-inclusive psychology, building in affiliation with and need for others into the very foundations of their accounts of human motivation, and denying that individuals can satisfy their basic desires independently of relationship and community. In a very important way Kant himself agrees: for although he holds that with respect to liking and pleasure and other forms of sensuous inclination we are not reliably inclined toward one another, he holds at the same time that the identity of a human being is given in the most fundamental terms by its membership in a certain sort of community, namely the kingdom of ends, the community of free rational beings 
who regard one another with respect and awe and who are committed to promote one another's happiness and well-being because of the respect they feel for one another. Rawls, similarly, imagines the agents in the Original Position as held together by a concern for building a community in which they will live together on terms of mutual cooperation.

As for normative ethical egoism, one could not even begin to argue plausibly that either the Utilitarian or the Kantian tradition is guilty. The essential emphasis of liberal individualism is on respect for others as individuals; how can this even initially be thought to involve egoism? Both theories are extremely exigent in the demands they make of moral agents in respect of altruism and duties to others. Utilitarianism holds that an action is right only if it maximizes total or average utility - of all the world's people, in its strictest version; some utilitarians would extend the requirement to animals as well. Clearly this is a theory that demands enormous sacrifices of agents, and is very far from letting them go about their self-interested business. Kantian duties to others are not quite as severe, since "imperfect duties" of bencvolence have much elasticity, and the Kantian agent is allowed to give preference on many occasions to the near and clear. Nonetheless, it would be utterly implausible to call Kant's an egoistic moral theory, since duties to promote the happiness of others are at its very core. ${ }^{25}$

More initially plausible is the suggestion that liberalism, by conceiving the human being in a way that imagines her cut off from all others and yet thriving, encourages normative projects of self-sufficiency-urges people, that is, to minimize their needs for one another and to depend on themselves alone. This, I think, is what Jaggar is really worried about when she speaks of "political solipsism". This is certainly one of the charges feminists commonly think true of liberalism, and one of the ways in which feminists have connected liberalism with common male attitudes and concerns. Feminists hold that by encouraging self-sufficiency as a goal, liberalism subverts the values of family and community, ends that feminists rightly prize. What should we say about this charge?

First, we should note that the normative goal of self-sufficiency is not one that feminists should dismiss without an argument. Those figures in the Western philosophical tradition who have defended some form of detachment and self-sufficiency as human goals-in particular, the Stoics and Spinoza-have done so using powerful arguments, in particular arguments that connect the aim of self-sufficiency with 
the elimination of anger and revenge, and the creation of a just and merciful society. Even if feminists want to reject those arguments, they need to grapple with them, rather than viewing them as so many signs of heedless maleness. ${ }^{26}$

Moreover, self-sufficiency is a goal that has actually been endorsed by some very valuable feminist projects in the developing world, those focusing on the empowerment of women through employment, credit, and land rights. SEWA, the Self-Employed Women's Organization, a very impressive project in India that gives loans to large numbers of women to improve their economic condition and also bargains on their behalf for better working conditions in informal-sector activities, has ten official goals for women, of which Self-Sufficiency is the last, and in some ways the most important. The importance of self-sufficiency as goal derives from Gandhi's thought about the importance of a selfreliant India; it also reflects the view of the organizers that women can only improve their bargaining position in the family through the pursuit of more independence from others. In the view of Ela Bhatt and the other leaders of SEWA, there is no contradiction between promoting self-sufficiency as goal and promoting valuable types of care and community. ${ }^{27}$ This seems right: self-sufficiency of a type may be pursued as one goal among others, and this need not subvert the most valuable types of affiliation.

Second, if we focus for the moment only on the more extreme forms of self-sufficiency, that do entail detachment from others, we should observe that the ethical aim of detachment is not strongly linked to individualism, that is, to the view that the primary focus of ethical and political thought should be the individual, understood as a separate unit. Indeed, in its most influential world form, in the Buddhist and to some extent also Hindu traditions, the normative doctrine of selfsufficiency and detachment presupposes the recognition that individuals as such do not really exist; it is precisely this recognition that grounds indifference to events, such as deaths of loved ones, that might be thought to matter deeply. Individualism, with its focus on what happens here and now in one's very own life, would seem to have an uphill battle in order to cultivate detachment from such external events. $^{28}$

Next, we should remark that even if the psychology of liberalism were as described, that is, even if liberals did hold that our most basic desires can be satisfied inclependently of relationships to others, the normative conclusions about extreme self-sufficiency would not follow. For moral theories frequently demand of people things that go 
against the grain, and we could demand great concern for others from people to whom such concern does not seem to come naturally. Such appears to have been the enterprise of Jeremy Bentham, who combined an extremely self-centered psychology with an exigent normative altruism. Kant, too, was ready to clemand of agents that they disregard their most powerful desires; he famously holds that even a man in whose heart nature has placed little sympathy for others can still be expected to be absolutely committed to their good, both in family and in community. Kant certainly believes that all altruistic commitment and loving concern in marriage goes against the grain, given the extremely solipsistic tendencies he imputes to sexual desire; but he expected individuals to live up to those commitments, rather than to seek self-sufficiency. ${ }^{29}$ Liberals, then, can and do highly value benevolence, family concern, and social/political involvement, even if they should hold that individuals must control strong selfish inclinations in order to pursue these things. And, as I have argued, liberalism typically endows individuals with powerful other-regarding motives also.

Liberal individualism, then, does not entail either egoism or normative self-sufficiency. What does it really mean, then, to make the individual the basic unit for political thought? It means, first of all, that liberalism responds sharply to the basic fact that each person has a course from birth to death that is not precisely the same as that of any other person; that each person is one and not more than one, that each feels pain in his or her own body, that the food given to A does not arrive in the stomach of $B$. The separateness of persons is a basic fact of human life; in stressing it, liberalism stresses something experientially true, and fundamentally important. In stressing this fact, the liberal takes her stand squarely in the camp of this-worldly experience, and rejects forms of revisionary metaphysics (for example forms of Buddhism or of Platonism) that would deny the reality of our separateness and our substantial embodied character. ${ }^{30}$ It rejects the Buddhist picture of persons as mere whorls in the ceaseless flux of world energy and the feudal picture of persons as fundamentally characterized by a set of hierarchical relations. It says that the fundamental entity for politics is a living body that goes from here to there, from birth to death, never fused with any other-that we are hungry and joyful and loving and needy one by one, however closely we may embrace one another. ${ }^{31}$ In normative terms, this commitment to the recognition of individual separateness means, for the liberal, that the demands of a collectivity or a relation should not as such be made the 
basic goal of politics: collectivities, such as the state and even the family, are composed of individuals, who never do fuse, who always continue to have their separate brains and voices and stomachs, however much they love one another. Each one of these is separate, and each one of these is an end. Liberalism holds that the flourishing of human beings taken one by one is both analytically and normatively prior to the flourishing of the state or the nation or the religious group: analytically, because such unities do not really efface the separate reality of individual lives, normatively because the recognition of that separateness is held to be a fundamental fact for ethics, which should recognize each separate entity as an end, not as a means to the ends of others. The central question of politics should be not, how is the organic whole doing, but rather, how are $X$ and $Y$ and $Z$ and $Q$ doing; the central goal for politics will be some sort of amelioration in the lives of $X$ and $Y$ and $Z$ and $Q$, where a larger amoumt of happiness for $X$, where $X$ might be the ruler, does not compensate for a larger amount of misery for $Q$ where $Q$ might be a poor rural woman. 32

Putting things this way does not require us to deny that $X$ might love $Y$ intensely, and view his life as worthless without $Y$; it does not require that $Z$ and $Q$ do not plan their lives together and aim at shared ends; it does not require us to hold that all four do not need one another profoundly, or vividly hold the pleasure and pain of one another in their imaginations. It just asks us to concern ourselves with the distribution of resources and opportunities in a certain way, namely, with concern to see how well each and pory one of them is doing, secing each and every one as an end, worthy of concern.

Put this way, liberal individualism seems to be a very good view for feminists to embrace. For it is clear that women have too rarely been treated as ends in themselves, and all too frequently treated as means to the ends of others. Women's individual well-being has far too rarely been taken into account in political and economic planning and measurement. Women have very often been treated as parts of a larger unit, especially the family, and valued primarily for their contribution as reproducers and care-givers, rather than as sources of agency and worth in their own right. In connection with this non-individualistic way of valuing women, questions about families have been asked without asking how well each of its individual members are doing. But conflicts for resources and opportunities are ubiquitous in families around the world, and women are often the victims of these conflicts. When food is scarce in families, it is very fiequently 
women, and especially girls, who get less, who become malnourished and die. When there is an illness and only some children can be taken to the doctor, it is frequently girls who are neglected. Amartya Sen's well-known statistic of "missing women" estimates that approximately 100 million women are not alive in the world today who would have been alive had they received nutrition and health care equal to that given males. ${ }^{33}$ There are 44 million such "missing women" in China alone, $\mathbf{3 6 . 9}$ million in India. In India, the "missing women" comprise 9.5\% of the total number of actual women, in Pakistan 12.9\%. Again, when only some children can go to school, it is frequently the girls who are kept at home. In South Asia, female literacy rates average around half those of males; in some countries the ratio is still lower: for example, in Afghanistan $32 \%$, in Sudan $27 \% .^{34}$

Again, when there is violence in the family, women and girls are overwhelmingly likely to be its victims. Here there are depressingly many statistics, but to cite just a few: The UN Human Development Report for 1995 reports that one third of women in Barbados, Canada, the Netherlands, New Zealand, Norway, and the United States report sexual abuse during childhood or adolescence. Each year, an estimated one million children (mostly girls in Asia) are forced into prostitution, often with the connivance of their families. An estimated 85 million living women and girls currently alive have suffered genital mutilation. ${ }^{35}$ In Colombia during 1982 and 1983, the Forensic Institute of Bogota found that of 1170 cases of bodily injury, one of five was due to conjugal violenct, and $94 \%$ of those hospitalized were battered women. More than $50 \%$ of married women in the largest slum of Bangkok reported being regularly beaten by their husbands. ${ }^{36}$ In the maternity hospital of Lima Peru, $90 \%$ of all young mothers ages twelve to sixteen have been raped by their father, stepfather, or another close relative. In Costa Rica, an agency working with young mothers reports that $95 \%$ of their pregnant clients under age fifteen are victims of incest. US data show that more than $50 \%$ of rape victims are age fifteen and under ${ }^{37}$ As for marriage itself, many of the world's women do not have the right to consent to a marriage, and few have any recourse from ill-treatment within it. Divorce, even if legally available, is commonly not a practical option, given women's economic dependency and lack of educational and employment opportunities. Marital rape is a ubiquitous fact of female life; both Western and non-Western nations have been culpably slow to criminalize it. ${ }^{38}$

To people who live in the midst of such facts, it is very important to say, I am a separate person and an individual. I count for some- 
thing as such, and my pain is not wiped out by someone else's satisfaction. When we reflect that a large number of the world's women inhabit traditions that really have denied the separateness of persons, and that many more inhabit traditions that, whatever their metaphysics, value women primarily for the care they give to others rather than as ends, we have all the more reason to insist that liberalism individualism is good for women. ${ }^{39}$

There is no doubt that liberalism deserves feminist criticism on this point. For, as many feminists have long pointed out, where women and the family are concerned, tiberal political thought has not been nearly individualist enough. Liberal thinkers tended to segment the private from the public sphere, considering the public sphere to be the sphere of individual rights and contractual arrangements, the family to be a private sphere of love and comfort into which the state should not meddle. This tendency grows, no doubt, out of a legitimate concern for the protection of choice-but too few questions were asked about whose choices were thereby protected. This meant that liberals often failed to notice the extent to which law and institutional arrangements shape the family institution and determine the privileges and rights of its members. Having failed to notice this, they all too frequently failed to ask whether there were legal deficiencies in this sphere that urgently necded addressing. In 1869 John Stuart Mill already urged British law to address the problem of marital rape, which, he said, made the lot of women lower than that of slaves:

Hardly any slave...is a slave at all hours and all minutes... But it cannot be so with the wife. Above all, a female slave has (in Christian countries) an admitted right, and is considered under a moral obligation, to refuse to her master the last familiarity. Not so the wife: however brutal a tyrant she may unfortunately be chained to-though she may know that he hates her, though it may be his daily pleasure to corture her, and though she may feel it impossible not to loathe him-he can claim from her and enforce the lowest degradation of a human being, that of being made the instrument of an animal function contrary (o) her inclinations. ${ }^{* 1}$

Though Mill seems excessively sanguine here about the female slave," he is right on target about the wife, and he sees what a decp violation of basic liberal tenets is involved in the failure to legislate against marital rape. Again, in the same passage, he argues that the laws that deny the wife equal legal rights over children are also a profound violation 
of personhood and autonomy. ${ }^{12}$ In a similar way, he diagnoses other distortions of the family structure caused by male power and the laws that expressed it, arguing for women's full equality in all that relates to citizenship, and therefore for many changes in disabling family laws.

Mill supports his argument in part by appeal to consistency, saying that liberalism cannot plausibly deny women the rights it vindicates for men. But he also argues that male citizenship in a liberal regime is ill served by a mode of family organization based upon subordination. For such a family order is a vestige of monarchical power, and raises up little despots who are ill prepared to respect the rights and dignity of their fellow citizens.

Think what it is to a boy, to grow up to manhood in the belief that without any merit or any exertion of his own, though he may be the most frivolous and empty or the most ignorant and stolid of mankind, by the mere fact of being born a male he is by right the superior of all and every one of an entire half of the human race: including probably some whose real superiority to himself he has daily or hourly occasion to feel...Is it imagined that all this does not pervert the whole manner of existence of the man, both as an individual and as a social being? It is an exact parallel to the fecling of a hereditary king that he is excellent above others by being born a king, or a noble by being born a noble. The relation between husband and wife is very like that between lord and vassal, except that the wife is held to more unlimited obedience than the vassal was. However the vassal's character may have been affected, for better or worse, by his subordination, who can help seeing that the lord's was affected greatly for the worse?... The self-worship of the monarch, or of the feudal superior, is matched by the self-worship of the male. Human beings do not grow up from childhood in the possession of unearned distinctions, without pluming themselves upon them. ${ }^{43}$

In short, Mill argues, the stability of a liberal regime demands the legal reform of family structure. All liberals should and must seck the "advantage of having the most universal and pervading of all human relations regulated by justice instead of injustice ${ }^{\text {.1.t }}$

Mill's arguments in The Subjection of Women showed that a concern for the individual well-being of family members, and a determination to use law and public policy to further that concern, were in no way alien to liberalism. Indeed, they grew naturally, as he shows, out of 
liberalism's concern for the fair treatment of each and every individual and its disdain for feudalism and monarchical power, for the castelike ascendancy of morally irrelevant distinctions. But most of the liberal tradition did not follow Mill's lead. Thus John Rawls, while envisaging a society in which each individual's well-being would be a matter of social concern, still imagined the contracting individuals as heads of households, who would be expected to take thought altruistically for the interests of family members. ${ }^{45}$ Here Rawls adopted a strategy similar to that of economist Gary Becker, whose model of the family has had enormous influence on information gathering and policy modeling around the worlcl. Becker held that for purposes of modeling we should assume that the head of the household is a beneficent altruist who will adequately take thought for the interests of all family members. Becker now holds that the model assumed too much altruism, and that many other motives, including anger, fear, and guilt would play a part in an adequate model of family transactions. Liberal reluctance to interfere with or even to judge the family has run very deep, and shockingly many liberal thinkers have not noticed that the family is not in fact always characterized by a harmony of interest, that males are not always beneficent altruists. ${ }^{46}$ No model of the family can be adequate to reality if it fails to take account of competition for scarce resources, divergent interests, and differences of power. ${ }^{17}$

Liberalism has much to learn from feminism in this area. It should begin by learning the facts of women's hunger, domestic violence, marital rape, unequal access to education. It should go on to correct these facts by laws and by moral education. It should also consider the implications of women's individuality for many traditional areas of law and policy, prominently including divorce ${ }^{\text {t8 }}$ and taxation. ${ }^{49}$ But notice that, as Mill already argued, what we see here is not at failure intrinsic to liberalism itself. It is, in fact, a failure of liberal thinkers to follow their own thought through to its socially radical conclusion. What is wrong with the views of the family endorsed by Becker, Rawls, and others is not that they are too individualist, but that they are not individualist enough. They assume too much organic unity and harmony. They give people too much credit for altruism and are not worried enough about the damages of competition. For this reason they fail to ask rigorously their own question, namely, how is each and every individual cloing? They fail to ask this, perhaps, because they are focused on the attonomy and freedom of males, and they want to give these males plenty of scope for planning their lives in the private sphere. But that is not the liberal traclition, when this freedom is bought at 
the expense of violence and death to other individuals. To treat males this way is, as Mill said, tantamount to treating them as kings, who have a hereditary title to subordinate others. To treat any group or person this way runs counter to the deepest instincts of the liberal tradition. Despotism must be curtailed by laws protecting the equality of citizens, whether or not this despotism occurs within the family. The public conception of a liberal society should be a place of refuge and dignity for those whose personal relations, without legal intervention, would not have guaranteed this dignity.

Notice that Mill claims not only that these reforms are just and that they protect the dignity and well-being of women. He claims, as well, that they are essential to promoting the dignity and well-being of men. Hierarchy is bad for the ruler too. Instead of proper selfrespect, he develops vanity; instead of relations of reciprocity and mutuality, he becomes habituated to relationships of exploitation and use. "In this sense," comments Roop Rekha Verma, developing these points in the context of contemporary India, "the feminist struggle must be viewed as the struggle for the liberation of humanity as a whole. ${ }^{50}$ But that struggle, against the background of feudalism, is what liberalism is all about.

For these reasons major theoretical and practical attempts to remedy the wrongs done to women in the family have been able to propose internal criticisms of liberalism, rather than its wholesale rejection. Susan Moller Okin's Justice, Gender, and the Family critizes liberal theory severely for their failure to consider injustice in the family. But she argues, plausibly, that John Rawls's theory of justice can be reformulated-along lines suggested by Rawls himself when he insisted that the family was one of the institutions that is part of the "basic structure of society" to be ordered in accordance with principles of justice. ${ }^{51}$ In this feminist reformulation, parties in the original position would be individuals, rather than representatives of household units ${ }^{52}$; and parties in the original position, in addition to being ignorant of their wealth, class, and conception of the good, would also be ignorant of their sex. Okin argues that this would lead them to design institutions in which the influence of gender (that is, of the social hierarchies correlated with biological sex) was minimized, and opportunities and resources would be equitably distributed within the family. ${ }^{53}$ Rawls appears to have accepted this proposal. ${ }^{54}$

In a very similar manner, international women's activists, taking international human rights agencies to task for their neglect of issues such as marital rape, domestic violence, marital consent, and women's 
hunger, have not moved to jettison the language of human rights. Instead, they have insisted that the major rights already on the agenda be vindicated for women, and also that rights of women to be free from gender-specific abuses be added to the list of human rights. Once again, the defect found in international agencies such as the United Nations is not that they have stressed individualism too much, but that, deferring to tradition and male power, they have not done so consistently and deeply enough. Charlotte Bunch, who coordinated the Global Campaign for Women's Human Rights at the United Nations 1993 World Conference on Human Rights, eloquently describes the feminist liberal program:

The concept of human rights, like all vibrant visions, is not static or the property of any one group; rather, its meaning expands as people reconceive of their needs and hopes in relation to it. In this spirit, feminists redefine human rights abuses to include the degradation and violation of women..$^{55}$

This liberal program is already producing transformations in many countries. Some rights language in constitutions and statues around the world is vague and aspirational, of little help to women who actually suffer from abuse. But there is indeed change. Consider a 1982 case in Bangladesh, Nelly Zaman v. Ghiyasuddin. ${ }^{56}$ A woman trapped in a violent and abusive marriage sought to exercise her legal right to divorce. The husband challenged, seeking restitution of his conjugal rights. Although the woman's right to divorce was clearly established by the marriage contract, the lower court held that she had "no right to divorce at her own sweet will and without any reasonable excuse." Her rights were vindicated by the High Court, which commented as follows:

The very concept of the husband's unilateral plea for forcible restitution of conjugal rights had become outmoded and...does not fit with the State and Public Principle and Policy of equality of all men and women being citizens equal before the law and entitled to be treated only in accordance with the law as guaranteed in Articles 27 and 31 of the Constitution.

In such small victories, which, taken cumulatively, can have a radical impact on the conduct of daily life, ${ }^{57}$ women have been winning the right to be recognized as separate beings, beings whose well being is distinct from that of a husband's, and who have a life of their own to live. In a similar manner, the widows who gathered in Bangalore 
were learning to think of themselves not as discarded adjuncts of a family unit, half dead things, but as centers of thought and choice and action, citizens who could make claims against the state for respect and for resources. All this is liberal individualism, and liberal individualism, consistently followed through, entails a radical feminist program. Most liberal political thinkers of the past have not consistently followed out this program. While talking about separateness and personhood, they did not take the separate personhood of women seriously enough. While objecting to some instances of feudal and monarchical power, they did not object to that power when it was justified by the accident of gender. Whether this omission is explained by convention or cowardice or disdain or inadvertence, it is culpable, and it has done great harm. But we see here the failure of people, not the failure of liberalism.

A deep strategic question arises at this point. When liberal people and states prove obtuse, refusing women's legitimate demands to be treated as ends, at what point should women-in pursuit of that liberal end-prefer revolutionary strategies that depart from libetal politics? Many feminists have discovered that Mill is correct: "the generality of the male sex cannot yet tolerate the idea of living with an equal." In consequence, legitimate arguments are met, again and again, not with rational engagement but with a resistance that kecps "throwing up fresh intrenchments of argument to repair any breach made in the old," but is in actuality quite impervious to reason. ${ }^{58}$ The pretense of argument frequently proves a mask for strategy aimed at shoring up power. This sort of thing makes revolutionary collective action deeply attractive to many women, in many different circumstances. And indeed, in many parts of the world, women have to at least some extent advanced their well-being through alliance with Marxist movements. It is beyond my scope here to give an account of when it is acceptable to use illiberal means for liberal ends, or to give advice to women who are faced (as for example in contemporary Afganistan) with the choice between religious fundamentalism and Marxist collectivism, or (as in contemporary Poland) between traditionalist religious parties and Marxist parties. Even in the United States and Britain, the repeated experience of male irrationality may legitimately cause many feminists to find liberal politics insufficiently radical. To one who repeatedly contends against opposition of the sort Mill describes, the desire to wipe the slate clean of such entrenched obstacles and to begin anew can seem deeply attractive. I wish to note only two things: first, that in the long run it is unlikely that liberal ends 
will be effectively served by collectivist means-as women in China have had ample occasion to note; second, that any noble ideal can be used as a screen by those who wish to do harm. The right response is to blame and expose the abusers, not to discard the ideal.

\section{Abstraction and Concrete Reality}

Closely related to the feminist critique of liberal individualism is the criticism that liberalism's vision of persons is too abstract. By thinking of individuals in ways that sever them from their history and their social context, liberal thinkers have deprived themselves of crucial insights. I believe that there are two different criticisms here. The first has great power, but can be addressed within liberalism; the second is a genuine attack upon liberalism, but does not give us a good reason to reject liberalism.

The first attack is pressed by Catharine Mackinnon, Alison Jaggar, and a number of other feminist thinkers. ${ }^{59}$ Their claim is that liberalism's disregard of differences between persons that are a product of history and social setting makes it adopt an unacceptably formal conception of equality, one that cannot in the end treat individuals as equals, given the reality of social hierarchy and unequal power. Notice that if this were so, that would be an extremely serious imtemal criticism of liberalism, whose central goal is to show equal respect for persons despite actual differences of power. What do these feminist critics have in mind?

It seems plausible that the liberal principle of formally equal treatment, equality under the law, may, if it is applied in an excessively abstract or remote manner, end up failing to show equal respect for persons. For example, one might use basically liberal language to justify schooling children of different races in separate schools: so long as the schools are equal, the children have been treated as equal; and if any disadvantage attaches to the separation, it is an equal disadvantage to them both. This, in fact, was the reasoning of Herbert Wechsler in a famous article critical of the reasoning in Brown vs. Board of Education, the landmark school-desegregation case. ${ }^{60}$ Insisting on alstraction for reasons of liberal equality and neutrality, Wechsler held that the introduction into evidence of the history of racial stigmatization and inequality was illegitimate, and could only result in a biased judgment "tailored to the immediate result." Similar reasoning has been used in cases involving gender. In a 1994 sexual harassment case brought by the first woman to work in the tinsmith shop in the 
General Motors plant in Indiana, the lower court judge, abstracting from the asymmetry of power between Carr and her male co-workers, held that the continual use of obscenities toward Carr by the male workers was exactly the same as the occasional use of a four-letter word by Carr: both reflected only the "ribald banter of the tinsmith's shop". Judge Posner, overruling the lower court judge on the findings of fact, held that the asymmetry of power-including its social meaning in historical terms-was a crucial part of the facts of the case. ${ }^{61}$ Their use of language was harassing and intimidating in a way that hers could not be. If liberal neutrality forbids one to take cognizance of such facts, this would indeed be a grave difficulty for liberalism.

In general, liberalism has sometimes been taken to require that the law be "sex-blind", behaving as if the social reality before us were a neutral starting point, and refusing to recognize ways in which the status quo embodies historical asymmetries of power. Feminists have worried, for example, that this sort of neutrality will prevent them from demanding pregnancy and maternity leaves as parts of women's equality of opportunity. ${ }^{62}$ Many feminists support a variety of affirmative action programs based on women's history of disadvantage and subordination. If liberal feminism would prevent the government of Bangladesh from investing its money disproportionately in literacy programs aimed at women, or in job training programs for women, this would lose liberalism the regard of most thinkers about women in international politics-including not only leading feminists such as Catharine MacKinnon, who is commonly described as a radical, but including also Gary Becker, who, in his column in Business Week has argued for government support for female literacy in connection with global population control. In short, to a wide range of thinkers, formal neutrality of an abstract sort makes little sense, when one is confronted with entrenched asymmetries of power. ${ }^{6.9}$

It seems to me mistaken, however, to think that liberalism has ever been committed to this type of unrealistic and ahistorical abstraction. ${ }^{64}$ Mackinnon is absolutely correct to think that some liberal legal thinkers, and some important Supreme Court decisions, have been guilty of this error; her critique of liberal equality theory is a valuable and correct critique of positions that have been influential in the law. But liberal philosophers have, on the whole, seen more deeply-and, I would say, more consistently - when they have rejected the purely formal notion of equality. Liberals standardly grant that the equality of opportunity that individuals have a right to demand from their governments has material prerequisites, and that these prerequisites may 
vary depending on one's situation in society. One way of putting this that Amartya Sen and I have favored is to say that liberalism aims at creating equality of capabilities, meaning that the aim is not just to distribute some resources around, but also to see that they truly go to work in promoting the capacity of people to choose a life in accordance with their own thinking. ${ }^{63}$ We think that the sort of liberalism best equipped to handle this task is one that is slightly less neutral about what human functions are important and valuable than classical Kantian liberalism. ${ }^{66}$ The differences between our view and Rawls's on this issue are highly subtle, however, and squarely within the mainstream liberal tradition. ${ }^{67}$

More important for our present purposes, even Rawls, with his great care not to bring any definite conception of the good into the formulation of society's basic structure, nonetheless provides political thought with ample resources to think well about difference and hierarchy. He insists very strongly on a distinction between merely formal equal liberty and what he calls the "equal worth of liberty," and also between formal equality of opportunity and truly fair equality of opportunity; the latter members of each pair have material prerequisites that are likely to involve redistribution. The parties in Rawls's original position do not know what group they themselves belong to; but they know all pertinent general facts about economics, politics, and human psychology-and presumably facts about race and gender relations would be among such general facts. The general principles they will choose will guarantee the equal worth of the various liberties and fully fair equality of opportunity to members of disadvantaged groups. In applying those principles at the constitutional and legislative phases, with fuller information, they would certainly judge that "separate but equal" schools did not given the history of race relations, guarantee fair equality of opportunity. is Noting that women ubiquitously face special hurdles on the way to becoming equal, they could insist on allocating special resources to women's equality, whether through education or in other ways. They would do so in the name of equality itself, viewing it as a violation of equality not to do so.

One very good example of a liberal appeal to the worth of equality, used to oppose purely formal equality, is found in the 1983 case from India discussed in the Introduction, which declared unconstitutional the portion of the Hindu Marriage Act that mandated the restitution of conjugal rights. Judge Choudary noted that the remedy of restitution is available to both men and women-but, given the 
asymmetries of power in Indian society, the remedy is likely to be used only by males against females, and the resulting burdens (including that of pregnancy against her will) to be borne only by females. He concludes:

Thus the use of remedy of restitution of conjugal rights in reality becomes partial and one-sided and available only to the husband. The pledge of equal protection of laws is thus inherently incapable of being fulfilled by this matrimonial remedy in our Hindu society. As a result this remedy works in practice only as an oppression, to be operated by the husband for the husband against the wife. By treating the wife and the husband who are inherently unequal as equals, Section 9 of the Act offends the rule of equal protection of laws. ${ }^{69}$

One could not have a better expression of Mackinnon's critiqueand within the context of a clearly liberal legal conception, in which the right of all citizens to autonomy and privacy is the central issue in question. ${ }^{70}$

Liberals will continue to differ about the topic of differential treatment, especially in the area of affirmative action. Libertarian liberals allow wide latitude for advantages that individuals derive from morally irrelevant attributes of birth and social location, but are strict on the rules that should govern benefits, insisting on a type of neutrality in which morally irrelevant characteristics play no role in the design of distributive policies and programs. Rawlsian liberals, noting that individuals arrive in society with many advantages that they have already derived from morally irrelevant characteristics, think it not just reasonable but morally required to readjust things in order that individuals should not be kings and princes; they therefore permit themselves a more extensive scrutiny of the history of group hierarchy and subordination, rejecting abstractness at this point, as incompatible with a fully equal treatment. Feminist liberals have typically followed this strand of liberal thinking to at least some extent, ${ }^{71}$ and their criticisms of other ideas of neutrality have been very important in generating legal change.

The criticism, then, is a serious criticism of some parts of the liberal political and legal tradition, and of the obtusely remote language this tradition has sometimes chosen to characterize human affairs; but it can be and frequently has been accommodated within liberalism. To address it well, liberalism needs to pay close attention to history, and to the narratives of people who are in situations of inequality. This 


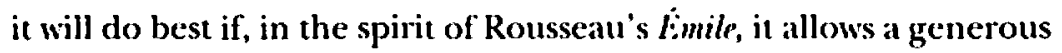
role for the imagination in the formulation and the writing of liberal theory. ${ }^{\text {in }}$

Another criticism of liberal abstractness cuts decper. ${ }^{73}$ Many communitarian thinkers, among them some feminists, have held that liberalism's determination to think of persons in abstraction from allegedly morally irrelevant features, stuch as birth, class, ethnicity, gender, religion, and race entails a pernicious form of "essentialism" that disregards the extent to which people are decply identified with their religious heritage, their ethnicity, and so forth, and the extent to which these social and historical differences shape people. In one sense, we could say again that this is just a mistake: liberalism is very interested in knowing these historical facts of difference, precisely in order to ensure fair equality of opportunity. ${ }^{7.4}$ But there is a decp point that is correct: liberalism does think that the core of rational and moral personhood is something all human beings share, shaped though it may be in different ways by their differing social circumstances. And it does give this core a special salience in political thought, defining the public realm in terms of it, purposefully refusing the same salience in the public political conception to differences of gender and rank and class and religion. ${ }^{75}$ This, of course, does not mean that people may not choose to identify themselves with their religion or ethnicity or gender, and to make that identification absolutely central in their lives. But for the liberal, that fact of choice is the essential fact; politics can take these features into account only in ways that are carefully structured in order to preserve respect for choice. This does not mean that these features of people's lives are treated as unimportant; indeed, in the case of religion it is because they are regarded as so important that any imposition on a person's conscicnce on these matters would be utterly inappropriate in the public political conception. ${ }^{76}$

At this point deep conflicts arise between liberalism and various religious and traditional views of life, insofar ats the latter hold that freedom of choice is not a central ethical goal. Even if those views are accommodated respectfully within a libemal polity, their adherents may fecl that respectful accommodation within a regime of toleration and free choice is not accommodation enough. Many delicate legal and political issues arise at this point. I shall not pursue them here.

The more urgent question for our purposes is, what values prized by feminists are likely to be slighted in this liberal emphasis upon choice? If women are understood to be, first and foremost, members 
of families, or members of religious traditions, or even members of ethnic groups—rather than, first and foremost, as human centers of choice and freedom-is this likely to be in any way better for women than is the "abstract individualism" of liberalism? Better in whose terms, we have to ask, and of course we will encounter at this point many religious women who sincerely hold that the account of their identity given in the Laws of Manu, ${ }^{77}$ or the Analects, or the Koran, or whatever, is superior vis a vis their flourishing to the account given in Kant and Mill. We cannot follow out all those lines of argument here-although we should note that all such views group people under abstract universal categories, and therefore cannot consistently attack liberalism for its own use of an abstract universal. ${ }^{78}$

But we can ask to what extent the same feminists who criticize liberalism for its abstractness can, in all consistency, jettison the liberal account of the human essence in favor of an account that gives more centrality to "accidental" features of religion or class or even gender. For these features are especially likely not to have been chosen by the women themselves, and to embody views of life that devalue and subordinate them. Even feminists who are themselves communitarians should be skeptical about accepting uncritically this feature of communitarian thought. Communitarianism need not be altogether uncritical of the status quo, and feminist communitarians can certainly avail themselves of liberal principles when criticizing an unjust social order. ${ }^{79}$ But feminists such as Jaggar and MacKinnon, who are generally critical of communitarian thought out of their concern for fundamental social change, should be especially skeptical of communitarian anti-essentialism. The idea that all human beings have a core of moral personhood that exerts claims on government no matter what the world has done to it is an idea that the women of the world badly need to vindicate their own equality and to argue for political and social change. If one thinks of a woman as just what the world has made of her, and that all existing distinctions are of equal moral relevance, one loses a grip on why this making is unjust. It is the disparity between humanity and its social deformation that gives rise to claims of justice. And the communitarian vision of persons, in which we are at heart and essentially what our traditions have made us, is a vision that leaves little scope for the type of critique of institutions and customs that feminists such as Jaggar and MacKinnon wish to make. ${ }^{80}$

One may make one further reply to feminists who stress the importance of recognizing differences of race and class. This is that the liberal approach is a principled approach that addresses itself to 
issues of human dignity in a completely general way. As a liberal feminist, one is also, by the entailment of one's very feminist position, also an anti-racist, a defender of religious toleration, and a supporter of fair equality of opportunity. One's feminism is not mere identity politics, putting the interests of women as such above the interests of other marginalized groups. It is part of a systematic and justifiable program that addresses exclusion and marginalization across the board in the name of human dignity. To that extent, the liberal feminist is in a better position than are many other feminists to show her fellow women that she has not neglected legitimate claims that are peculiar to their own class- or religion- or race-based identities.

As Onora O'Neill aptly says: feminism needs abstractness without unrealistic idealization. ${ }^{81}$ What she means by this is that feminism needs to operate with a general notion of the human core, without forgetting that this core has been differently situated and also shaped in different times and places. We should not overlook the questions raised by these differences, and we cannot formulate a just social policy if we do. But insofar as feminism cuts more deeply against liberalism, denying the salience and value of the whole idea of the human core, it gives up something vital to the most powerful feminist arguments. ${ }^{82}$

\section{Reason and Emotion}

Liberalism traditionally holds that human beings are above all reasoning beings, and that the dignity of reason is the primary source of human equality. As Jaggar puts it, "Liberal political theory is grounded on the conception of human beings as essentially rational agents. ${ }^{.83}$ Here liberal thinkers are not alone: they owe much to their forebears in the Western philosophical tradition, in particular the Greek and Roman Stoics, whose conception of the dignity of reason as a source of equal human worth profoundly influenced Kant, Adam Smith, John Rawls, and others as well. Continuing the Stoic heritage, liberalism typically holds that the relevant type of reason is practical reason, the capacity for understanding moral distinctions, for ranking and evaluating options, for selecting means to ends, and for planning a life. Thinkers have differed in the relative weight they assign to these different components, but not in their choice of practical over theoretical reasoning power as the essential mark of humanity.

Modern feminist thinkers usually grant that this liberal move has had at least some value for women in secking to secure their equality. They point out that earlier feminists, from Cartesian philosopher 
Mary Astell to Mary Wollstonecraft, were able to appeal to women's rational capacity as a ground for claims to full political and moral equatity. (They could indeed go much further back in history to support this claim: for Astell's arguments are closely related to the arguments of first-century A. D. Stoic Musonius Rufus, in his treatises "That Women Too Should Do Philosophy" and "Should Sons and Daughters Have the Same Education?") ${ }^{8-4}$ And they could reflect that the decision to base moral and political claims on an innate capacity of individuals, rather than on social endowments or positions or relations, is certainly one that opens the door to radical claims of empowerment for the disempowered, who can now say that they are the equals of kings, no matter where they are currently placed in society.

On the other hand, feminists have worried that liberalism is far too rationalist: that by placing all emphasis on reason as a mark of humanity, it has emphasized a trait that males traditionally prize and denigrated traits, such as sympathy and emotion and imagination, that females traditionally prize. This emphasis has permitted men to denigrate women for their emotional natures, and to marginalize them on account of their alleged lack of reason. This would not have been possible, the argument goes, had political philosophy been grounded in a conception that gave, at least, equal weight to reason and to emotion.

Most feminists who make such claims do not argue for innate differences between the sexes, although some do. ${ }^{85}$ Their argument is, more frequently, that women, as a result of their experiences of mothering and in general of family love and care, have rightly valued some important elements in human life that men frequently undervalue. ${ }^{86}$ Liberal philosophy is accused of making that common male error, in a way that frequently contributes to the denigration of women.

This is a complicated issue, since grappling with it fully would require us to argue for an account of what emotions are. The objection, as I have stated it, assumed that emotions are not forms of thought or reasoning, that there is a strong contrast to be drawn between reason and emotion. But is this true? Both the history of philosophy and contemporary psychological inquiry contain much debate on precisely that issue. On the whole, the dominant view, both in the Western philosophical tradition and in recent work in cognitive psychology is that emotions such as fear, anger, compassion, and grief involve evaluative appraisals that are full of imaginative and mental activity, appraisals in which the person (or animal) surveys the objects and persons in the world around him with an eye to how important goals and projects are doing. If one holds some such view of what emo- 
tions involve, then the entire distinction between reason and emotion begins to be called into question, and one can no longer assume that a thinker who focuses on reason is by that very move excluding emotion, or vice versa. ${ }^{87}$ So we must proceed cautiously here, looking both at the view of the emotion-reason contrast a thinker holds and also at the normative judgments the thinker makes about low good or valuable emotions are. This is tricky, because in the liberal tradition these positions cut across one another: thinkers who hold a strong form of the emotion-reason contrast disagree about the value they attach to emotions, as do thinkers who consider emotions to involve thought and evaluation. By trying to keep these distinctions straight we can make some progress in understanding the force of the feminist objections.

First, then, we do discover in the liberal tradition some philosophers who conceive of emotions as impulses distinct from reason, unintelligent forces that push the personality around. On this basis, they do endorse a contrast between reason and emotion. Kant and Hume are very different examples of this contrast (though neither has a simple non-cognitive view). One strong feminist objection against elements in the liberal tradition is the objection that this is an implausible and ultimately indefensible picture of what emotions are. ${ }^{88}$ To put a complex issue very briefly, it is implausible because it neglects the extent to which perceptions of an object and beliefs about the object are an intrinsic part of the experience of a complex emotion such as grief or fear. Grief, for example, is not simply a tug at the heart-strings: it involves the perception of an enormous void in the subject's life, and the belief that an object of great importance has been lost. Emotions involve ways of seeing. ${ }^{89}$ This objection has been made by all sorts of philosophers and psychologists independently of feminist concerns; but the feminist version of the objection suggests that the philosophers who put forward such a picute have been insufficiently reflective about the nature of emotional experience, and that this failure to look closely at experience may derive from a cultural suspiciousness of emotions that is frequently distributed along gender lines. 90

But even Kant and Hume, whatever the deficiencies in their analysis of emotions, are far from dismissing cmotions firom their normative picture of the moral life. Kant is guarded about the contribution of emotions to moral motivation, but even he sees a necessary role for pity in motivating benevolence; Hume sees the emotions as the source of all the ends that morality pursues. Modern feminist Annette Baier has recently defended Hume's conception of the passions as the one 
feminists ought to use. ${ }^{91}$ Although I am far from agreeing with Baier, since I think Hume's conception indefensible, ${ }^{92}$ I think she is right to acknowledge the central place Hume gives to passion in his account of human nature. So even if major liberal thinkers have failed to appreciate sufficiently the amount of intelligence involved in emotion, this has not altogether stopped them from valuing the contribution of emotion to our moral choices.

Let me now turn to the cognitive conceptions of emotion. Quite a few philosophers who focus on reason, and who make reason a hallmark of the human, have, in fact, a strongly cognitive conception of emotion, and think of emotions as activities of the rational faculty. Among these philosophers are some ancestors of liberalism, such as the Stoics and Spinoza. The Stoics and Spinoza dislike the emotions intensely; they do so, however, not on the grounds that emotions are not reason-based, but because they believe that the emotions involve false or confused reasoning, appraisals that ascribe to persons and things outside our own control more importance for our well-being than they actually possess. They hold this because of their normative views about individual self-sufficiency, which we have already discussed; these views are not widely shared in the liberal tradition. Feminists have suggested that these views derive from a male suspiciousness of all attachments. ${ }^{93}$ Whether or not there is truth in this suggestion, the Stoic anti-emotion position is certainly defended with other arguments as well, having to do with the containment of aggression and jealousy, and should be criticized with these arguments squarely in view.

But for those who reject those arguments, liberalism offers other resources. The position that many feminists would seem to favor, as doing most justice to women's experience of the value of emotional attachment and connection, would be a position that first analyzes emotions as containing cognition and then evaluates them positively, as having at least some value in the ethical life. This position is powerfully represented in the liberal tradition-to some extent under the influence of Aristotle, who influentially held such a position. Both Jean-Jacques Rousseau and Adam Smith seem to have held that emotions involve thought and imagination; they also hold that the capacity for sympathy is a central mark of both private and public rationality, and indeed of humanity as such. Rousseau holds that a person who has no capacity for feeling pain at the distress of others is not fully human, that this capacity for imaginative response is the essential thing that draws us together in community and makes political thought possible in the first place. Smith's entire account of the "judicious spec- 
tator" - his model of good public judgment-is preoccupied with ascertaining the correct balance in the passions of anger and sympathy and love that such a public actor will feel. These positions seem to be independent of their views about women's political role, which are remarkably conventional and non-progressive; nonetheless, they appear to be positions that offer what feminists have demanded. To this list we may certainly add Mill, whose Autobiography provides a moving testament to the barrenness of a rationality starved of emotional attachment and imaginative stimulation.

What, then, is the issue? What does this liberal tradition assert about emotions, that feminist thinkers might still wish to deny? The liberal tradition agrees that emotions should not be trusted as guides to life without being subjected to some sort of critical scrutiny. They are thought to be only as reliable as the evaluations they contain; and since such evaluations of objects are frequently absorbed from society, from its pictures of honor and status and worth, they will be only as reliable as those social norms. To naturalize them would be to naturalize the status quo. In general, emotions, like other forms of thought and imagination, should be valued as elements in a life governed by critical reasoning about what is just and good.

Some feminists, however, hold that this entire idea of subjecting emotion to rational appraisal is mistaken, an imposition of a male norm of cool rationality on the natural vigor and intensity of the passions. Unlike other feminist objections to liberal views of reason and emotion-which, as I have argued, are not accurate as directed against the strongest liberal positions-this one directly assails a central tenet of liberalism. Nel Noddings, a prominent proponent of this objection in her influential book Caring ${ }^{94}$, holds that women's experience of mothering reveals a rich terrain of emotional experience into which judgment and appraisal do not and should not enter. For example, there is a primitive bond of joy and love between mother and child that would be sullied by reflection, and this primitive unscrutinized love should be the model for our social attachments. From the perspective of a moral view such as Noddings's, liberalism, by urging people to ask whether their emotions are appropriate, robs moral life of a spontaneous movement toward others that is at the very core of morality. ${ }^{95}$ Unless we give ourselves away to others without asking questions, we have not behaved in a fully moral way. It is the very unreasoning and unjudicious character of maternal love and care that make it a fitting paradigm for social life.

Noddings appeals, here, to images of selfless giving that lie deep 
in the Jewish and Christian traditions, though her view would certainly be controversial in both. ${ }^{96}$ Noddings holds that her maternal paradigm of care is incompatible with norms of reflective caring that are preferred by liberalism. And Noddings is correct. The liberal tradition is profoundly opposed, at its heart, to the idea that people should spontaneously give themselves away without reflection, judgment, or reciprocity. At last, then, we have identified a position about the emotional life that is truly opposed to liberalism; it puts itself forward as a feminist position, since it appeals to maternal experience as a paradigm for all human concern. Liberalism says, let them give themselves away to others-provided that they so choose in all freedom. Noddings says that this is one thought too many-that love based on reflection lacks some of the spontaneity and monal value of true maternal love.

What should feminists say about this? First of all, I think, we should ask a good number of questions about Noddings's claim that maternal love and joy can and should be innocent of appraisal and judgment. She gives an example that makes at least one mother doubt.

There is the joy that unaccountably floods over me as I walk into the house and see my daughter asleep on the sofa. She is exhausted from basketball playing, and her hair lies curled on a damp forehead. The joy I feel is immediate... There is a feeling of connectedness in my joy, but no awareness of a particular belief and, certainly, no conscious assessment. ${ }^{97}$

Noddings concludes that such moments in which consciousness is emptied of focus and the personality simply flows toward another in a condition of fusion lie at the core of moral motivation.

Let us consider this allegedly thoughtless and objectless joy. Noddings thinks nothing; she simply basks in the fused experience of maternal caring. ${ }^{98}$ But can it really be the case that she has no thoughts at all? Doesn't Noddlings have to have, in fact, the belief that her daughter is alive and asleep on the couch, rather than dead? Change that belief, and her emotion would change from joy to devastating grief. She may not have to stop to ponder such a fact, but when her daughter was a baby she probably did. ${ }^{99}$ Again, doesn't her joy presuppose the recognition that it is her daughter there on the couch rather than a burglar who has broken in? Doesn't its intensity also presuppose a recognition of the central importance of her daughter in her life? To some extent, then, the view seems just wrong of the case as charac- 
terized. But to the extent to which Noddings does give in to a joy without thought, how wise is she to do so? It does not occur to her, for example, to ask whether her daughter is sleeping firom a drug or alcohol overdose, or following risky sex with a boyfriend, or sexual abuse from a relative. Assuming things are as she thinks, her joy is fine, and her maternal reactions morally appropriate. But aren't there circumstances in which the erasure of thought (which, as we sec, is not complete even in this example) could be pushed a little too far? If her daughter really is slecping from a heroin overdose, or is unconscious from sexual abuse, Noddings's joy would be inappropriate and her maternal responses harmful. Such heedless caring is dangerous, in a world where many of the forces affecting the lives of children are malign. Noddings may live in a world in which she may salely bracket those concerns, but most mothers do not.

As Nietzsche wrote in a related connection: Blessed are the slecpy ones-for they shall soon nod off. ${ }^{(1)}$

A child is not an arm or a leg or a wish, but a separate person. This person lives in a world full of both delight and danger. This means that the mother had better think, and it means that she had better teach her child how to think. And she had better think critically, asking whether the norms and traditions embodied in the emotions of fear and shame and honor in her society-and in her own emotions as well-are reasonable or unreasonable norms. What shall she teach her child to fear, and what not to fear? How shall she urge her child to see the stranger who offers her an ice cream, or the teacher who caresses her, or the friend who says that people with black skin are bad? Unless socicty is perfect, as it probably is not, critical thought needs to inform emotional development and response if caring is 10 produce good citizens. The suggestion of Smith and Rousseau that emotional responses should be scrutinized for their appropriateness to their object, and cultivated as parts of a life organized by reason, seems a better recipe for maternal care than Noddings's emphasis on thoughtless giving.

Even were symbiotic fiused caring a good thing in the mother-child relationship, a very different sort of care secms required in the political life. Here indiscriminate self-giving-away seems a very bad idea, especially for women, who have frequently been brought up to think that they should sacrifice their well-being to others without demanding anything for themselves. This has frequently served male interests and harmed women. We should not naturalize the status quos. A little reflection, far from representing "one thought too many," 
might provide the saving distance between social norms and one's own selfhood. In short, Noddings and her allies risk turning some of the pathologies of women's lives into virtues. Even in the family, there is no reason why women should simply give themselves away, without demanding a just distribution of resources.

Recall, now, the widows at the conference in Bangalore. Having spent most of their lives thinking of themselves as mere adjuncts of a family, with no rights and no separate identity, they started to learn not to give themselves away without thinking. And this seemed to be a good thing. The women themselves were delighted with their newfound self-expression and freedom, and the expansion in their set of choices itself seems a definite good. But still, we might ask: aren't these women being brainwashed by these liberal ideas? The widows in Bangalore gathered under the auspices of regional development workers and international activists, who had some pretty definite goals in mind, liberal goals. The Hindu article reports that the women were "urged" to think of themselves in a certain way; Noddings would presumably object that this way of thinking involves giving up a valuable kind of organic unity within the family that women had previously prized. Indian feminist Veena Das develops a similar position, arguing that the notion of personal welfare is alien to Indian women. ${ }^{102}$ If a typical Indian rural woman were to be asked about her personal "welfare," Das claims, she would find the question unintelligible, except as a question about how the whole family is doing. The thinking of these women, Das holds, exemplifies a valuable type of emotional devotion, which will be destroyed by the heavy hand of liberal individualism.

Here we must distinguish several different aspects of these women's familial devotion. Liberal individualism, I have argued, does not ask a woman to become an egoist, putting her own gratification first and other people's second. So far as liberalism is concerned, she may be (and in most versions ought to be) a committed altruist, even to the point of making considerable sacrifices of her own personal welfare for the sake of others. Nor, so far as liberalism is concerned, need she be dedicated to self-sufficiency, to minimizing her attachments to and needs from others. Again, she may continue to place friendship and love squarely at the heart of her plan. What liberalism asks, however, is that the woman distinguish the question of her own wellbeing from the question of the well-being of others, and notice what tensions might exist between the two, even if they are, as so often they are, bound up in one another. Liberalism asks, further, that a woman 
reflect and choose for herself the extent to which she will indeed sacrifice her own well-being for others-that she do so not out of habit or convention, but as the result of an individual decision, freely made. It is of course a large matter to spell out the conditions under which such choices would count as freely made, but we can at least agree that many conditions under which women make sacrifices (such as conditions of malnutrition, intimidation, lack of education, and lack of political power) are not such conditions. It is common for people to internalize the roles society gives them and to act unreflectively in accordance with these roles. People also adjust their desires and preferences to what is possible, so that they may even in a limited sense be content with their lot. But in circumstances of traditional hierarchy and limited information, we surely should not assume that the sacrifices of well being a woman makes are freely chosen, whatever account of free choice and autonomy we ultimately prefer. And this does seem to matter. As Rousseau and Smith and Mill would advise: let her love others and give herself away-provided that she does so freely and judiciously, with the proper critical scrutiny of the relevant social norms. I believe that this proposal, far from killing love through excessive male rationality, indicates the conditions under which love is a healthy part of a flourishing life. ${ }^{103}$

In fact, the most powerful criticism that feminists have made against liberal views of reason and emotion goes, I believe, in exactly the opposite direction from Noddings's proposal. This criticism, made most influentially by Catharine MacKinnon and Andrea Dworkin, and by now commonly accepted in at least some form, is that emotion, desire, and preference are not given or "natural," but powerfully shaped by social norms and appraisals-and that many emotions of both men and women are shaped by social norms that subordinate women to men. ${ }^{104}$ Mackinnon has powerfully argued that not only male aggression and female timidity, but also the character of both male and female sexual desire, are often powerfully influenced by the social norm that women ought to be the subordinates of men. Men eroticize domination and learn to achieve sexual satisfaction in connection with its assertion. Women come to eroticize submission and learn to find satisfaction by giving themselves away. This, Mackinnon has argued, is a profound detriment both to individuals and to society.

MacKinnon's insistence on recognizing and criticizing socially deformed preferences goes against one strand in contemporary liberalism, namely that part of economic utilitarianism that has standardly taken preferences as given, as a stable bedrock to which law and eco- 
nomics respond, rather than as material that is itself shaped by law and economics. Economists are now increasingly calling such views into question. ${ }^{105}$ Such views have always been profoundly at odds with the Kantian liberal tradition, which insists that individuals' desires are frequently distorted by self-interest. They are even more clearly at odds with the liberalisms of Adam Smith and Rousseau, both of whom were preoccupied with the criticism of diseased emotions and desires, and who saw bad social arrangements as at the core of those diseases. Rousseau powerfully shows how differences of rank corrupt human sympathy, preventing nobles from seeing their own pain in the pain they inflict on a peasant. ${ }^{106}$ Smith shows how the importance attached by socicty to money and status corrupt emotions of anger, love, and sympathy, producing people who are far from good citizens or good moral agents. ${ }^{107}$ Both follow the ancient Stoic tradition, according to which human beings are naturally good, and what is envious and malicious and aggressive in them results from social deformation. ${ }^{108}$

Nor are such insights at all foreign to the utilitarian tradition itself. Mill prominently recognized the social deformation of preferences, especially with regard to sex roles. Women, he held, internalize their inferior status in ways that shape their desires and choice, and many of these ways are very damaging to them and to society. He held that " $[w]$ hat is now called the nature of women is an eminently artificial thing - the result of forced repression in some directions, unnatural stimulation in others." It is, he says, as if one had grown a tree half in a vapor bath and half in the snow, and then, noting that one part of it is withered and another part luxuriant, had held that it was the nature of the tree to be that way. ${ }^{109}$ Men also find their desires shaped by the experience of domination. They become arrogant and overweening and malicious-again, in ways that are bad, both for them and for society. Mill draws special attention to the way in which socicty eroticizes female "meckncss, submissiveness and resignation of all individual will" as "an essential part of sexual attractiveness," whereas strength of will is eroticized in the case of men. ${ }^{110}$ Given the upbringing of women, it would be "a miracle if the object of being attractive to men had not become the polar star of feminine ecducation and formation of character, "III and equally miraculous if this object had not been understood to entail subordination. Here again, Mill makes a judicious comparison to feudalism: To both nobles and vassals, domination and subordination seemed natural, and the desires of both were shaped by this sense of the natural. Equality always seems unnatural to the dominator, and this is why any departure from 
women's subjection to men appears unnatural. "But how entirely, even in this case, the feeling is dependent on custom, appears by ample experience. "112

What is new and remarkable in the work of Mackinnon and Dworkin is the insight that even sexual desire-which has often been thought to be natural and presocial, even by thinkers who would not hold this of envy and fear and anger ${ }^{13}$ _has a social shaping, and that this shaping is often far from benign. Their central idea is already present in Mill, but they have developed it much further and given it shape and power, partly on account of the opportunity they have to discuss sexual matters with a candor unavailable to Mill. One may differ with many of their analyses and normative conclusions; but it seems hard to avoid granting that they have identified a phenomenon of immense human importance, one that lics at the heart of a great deal of human misery. Insofar as liberalism has left the private sphere unexamined, this critique of desire is a critique of liberalism. It challenges liberalism to do for desire what it has often done with greed and anger and envy-that is, to conduct a rigorous examination of the social formation of erotic longing and to think of the moral education of children with these aims in mind. As Mill shows us, such critical scrutiny of desire is right in line with liberalism's deepest aspirations.

Doesn't this ruin sex? As in the case of maternal caring, so here: doesn't the liberal ask women to have "one thought too many"? Doesn't sex at its best involve a heedless giving away of oneself to the other, an erasing of conscious reflection? Yes and no. Liberal feminism-and here $I$ believe it is right to treat Mackinnon as a kind of Kantian liberal, inspired by a deep vision of personhood and autonomy ${ }^{114}$-does not ask women not to abandon themselves to and in pleasure, any more than it asks them not to invest themselves deeply in caring for children and loved ones. Once again, however, it says: Fine, so long as you think first. Abandon yourself, so long as you do so within a context of equality and non-instrumental respect. ${ }^{11.5}$ In some areas of life, perhaps, non-instrumental respect can be taken for granted. In this onc, because of its history of distortion, it cannot be, and so you must think. If, as Mill plausibly suggests, "the generality of the male sex cannot yet tolerate the idea of living with an equal," this thinking will occasion tension, upheaval, and pain. The liberal holds that this pain should be risked rather than endure the hidden pain that arises from subordination and the passions it shapes.

In short, wherever you most mistrust habit, there you have the most 
need for reason. Women have lots of grounds to mistrust most habits people have had through the centuries, just as Rousseau's poor people have reason to mistrust the moral emotions of kings. This means that women have an especially great need for reason. Males can at least take consolation from the thought that the habits they live by have been formed by them, whether for good or for ill. Women should recognize that where the voice of tradition speaks, that voice is most often male, and it has even invented a little squeaky voice for women to speak in, a voice that may be far from being their own true voice, whatever precise content we attach to that idea.

In an age skeptical of reason, as Mill rightly argues, we have a hard time unmasking such deeply habitual fictions. Thus the romantic reaction against reason that he saw in his own time seemed to him profoundly subversive of any reform that goes against deeply seated custom. "For the apotheosis of Reason," he concludes, "we have substituted that of Instinct; and we call everything instinct which we find in ourselves and for which we cannot trace any rational foundation." Contemporary feminism beware of making the same mistake. ${ }^{117}$

Two things fill the mind with ever-increasing awe, wrote Kant: "the starry sky above me, and the moral law within me." 118 In that famous statement we see the radical vision of liberalism. Think what real people usually hold in awe: money, power, success, nice clothes, fancy cars, the dignity of kings, the wealth of corporations, the authority of vassals and lords and despots of all sorts-and, perhaps most important of all, the authority of custom and tradition. Think what real women frequently hold in awe, or at least in fear: the physical power of men, the authority of men in the workplace, the sexual allure of male power, the alleged maleness of the deity, the control males have over work and shelter and food. The liberal holds none of these things in awe. She feels reverence for the world, its mystery and its wonder. And she reveres the capacity of persons to choose and fashion a life. That capacity has no gender, so the liberal does not revere distinctions of gender, any more than the dazzling equipment of nobles and kings. Some liberal thinkers have in fact revered established distinctions of gender. But, insofar as they did, they did not follow the vision of liberalism far enough. It is the vision of a beautiful, rich, and difficult world, in which a community of persons regard one another as free and equal, but also as finite and needy-and therefore strive to arrange their relations on terms of justice and liberty. In a world governed by hierarchies of power and fashion, this is still, as it was from the first, a radical vision, a vision that can and should lead to social 
revolution. It is always radical to make the demand to see and to be seen as human, rather than as someone's lord, or someone's subject. I believe it is best for women to embrace this vision and make this demand.

\section{Notes}

1. Verma, "Femininity, Equality, and Personhood," Address delivered at the American Philosophical Association, December 1992, and published in Women, Cullure, and Detelopment: A Study of Iluman (appatilities (hereafier WCD), cel. M. Nussbaum and J. Glover (Oxford: (ilarendon Press, 1995). 433-43.

2. Toubia, "Female (ienital Mutilation," in Women is Rights, /luman Rights (hereafter WRHR), ed. Julie Peters and Andrea Wolper (New York and London: Routledge, 1995) 22+37, at 235; reprinted from Toubia, Femate Cenilal Mutilation: A Call for Clobal Artion (Women, lnc: 1993).

3. The Hindu, April 24, 1994.

4. Alison Jaggar. Feminist Politics and IJuman Nature (Tolowa: Rownan and Allatlheld, 1983, repr. 1988), 47-18. For related views, sec also Carole Pateman, The Problem of Political Obligation: A Cristique of Liberal Theory (Berkeley: Lniversity of (alifornia Press, 1979); Nancy (.. M. Hartsuck, Monn. Sex, and Pouer (Boston: Noribeastern L'niversity Press, 1983). An interesting response to some of the criticisms is in Marilyn Fricdman. -Feminism and Modern Friendship." lithics 99 (1989). 304-319.

5. Among many treatuments of these topics, see discussion of the issues in Amartya Sen, "Is Coercion a Part of Asian Values?" fortheoming. Sec also the exchange between Albie Sachs and Roberto Linger in Economir and Sorial Rights and the Right to Health Harvard Law School Human Rights Program (Cambridge, MA 1993), $12 \mathrm{fr}$.

6. Of course this power needs development; but the basis for human equality is the possession of the potentiality for that development. Even if inclividuals possess differing elegrees of this basic potentiality, we can say that a sufficient condition for equal moral personality is the possession of a certain basic minimum: see "The Basis of Equality;" section 77 in John Rawls, A Theony of Justice (Cambridge, MA: Havvard University Press, 1971), 504-312, and also my discussion of "basic copabilities," in "I luman Capabilities, Female Human Beings," in W(d). This was also the view of the ancient Stoics.

7. See M. Nussbaum, "Kutut and Stoic Cessmepolitanism," forthcoming in The Journal of Political Philosophy; also Julia Anmas, The Morality of Happiness (New York: Oxford University Press, 1993).

8. This characterization of the essence of the liberal tratlition differs sharply from that given in Ronald! 1)workin, "liberalism," in A Matier of Principle (Cambridge. MA: 1 larvard University Press, 1985), 181-204. Dworkin makes neutrality about conceptions of the good the basic core of liberalism, rather than any more positive ideal. I would hold that to the exient that liberals ate neutral albout the geod, this is explained by the basic intution alout the worth of choice and the respect for the choicemaking capacities of the persom. Rawls, for example, secms to me to have a far decper account of the core of liberalisen when he loggins from an idea of "free and equal moral persons" and derives a measure of neutrality about the good from that idea. See particularly Kantian Constructivism and Moral Theon: The Deney Isetures 1980, Lecture I: "Rational and Full Autonomy," The foumal of Philosophy 77 (i980) pp. 521 ff., and "The l'riorily of Right aund ldeas of the Cood," Philosophy amd Public Affairs 17 (1988) 251-76.

9. This idea is central in both the Kantian and the Utilitarian traditions. See the exkensive discussion in John Rawls, A Theory of Justice (Cambridge, MA: Hatvard University l'ress, 1971), 11-16, 118-30, ctc. For its relation w US constitutional law, see Cass R. Sunstein, The Partial Constitution (Cambridge, MA: Harvard University Press, 1993). 
10. Some libertarian oflshoots of liberalism might be charged with having lost that central idea, insofar as they validate existing distributions that have morally irrelevant origins. Some liberals will claim that personal talents and capacities other than the moral faculties ought to be counted as part of the core of the person, and thus, insofar as they confer adsantage, as not morally irrelevant; this is one source of the gulf between Nozick and Rawls. But some libertarian arguments also validate existing hierarchies of wealth and class; unless they do so by deriving those advantages from the moral rights of persons (as Nozick tries to do), they are by my account illiberal. For a judicious analysis of Nozick's relationship to two strands of the liberal tradition, sece Barbaun Fried, "Wil, Chamberlain Revisited: Nozick's "Justice in Transfer" and the Problem of Market-Based Distribution," Philosophy and Public AfJairs 24 (1995), 226-45.

11. Thus there is room for doubt whether classical utilitarianism is not, in the end, illiberal, in the sense that it treats the desires of all persons as fusable into a single system and ignores the silience of the separateness of persons. This is the primary criticism of utilitarianism developed in the Kantian tradition: sec, for example, Rawls, $A$ Theory of Justice, pp. 183-92, 55+-9.

12. For some of the opponents, see Stephen Holmes, The Anatomy of Anti-Liberalism (Cambridge, MA:Haryard University Press, 1993).

13. Rawls, A Theory of Justice, Nozick, Anarchy, State, and Vtopia (Oxford: Basil Blackwell, 1974). Both understand themselves to be heirs and rival interpreters of the liberal tradition; in characterizing their difference this way I am not saying anyuhing particularly new or sturprising. On this point, sec the clear account in $R$. Dworkin, in Men of Ifeas, ed. B. Magec. Nozick is clear that his own validation of existing differences of wealth and class depends on an argument from basic rights of self-ownership and just transfer, and that inequalities that cannot be so justified are unacceptable. His decpest difference from Kintian liberalism is his unargued assumption that features of persons other than the basis of their moral powers have moral weight and relevance: fentures such as talent in sports, physical strength, cleverness, etc.

14. On this distinction, see Henry S. Richardson, Practical Deliberation of Final Ends (New York: Cambridge University Press, 1994), 69-86, 209-27.

15. Even in this area, liberals will differ. Thus, for example, in the area of legal regtuation of speech. Cass Sumstein's view holds that political speech is the central type that government needs to protect in protecting respect for persons; Joshua Cohen argues, in contrast, that artistic speech is also wortlyy of protection as embodying expressive capacities that are central to personhood. See Sunstein, Democracy and the Problem of Free Speech (New York: The Free Press, 1993), pp. ; Cohen, "Freedom of Expression," Philesophy and Public Affairs 22 (1993), pp. 207-63. Once again, we see here differences not only about strategies to achieve equal respect, but, as well, about the more concrete specification of the notions involved, such as personhood and autonomy. On specification, with respect to liberal politics, see Richardson, Practical Deliberation, 20927, esp. $218-27$.

A note on US politics. In terms of my discussion here, all major positions represented on the US political scene are to at least some degree liberal positions, insofar as they defend the Constitution. The strongest inclinations to anti-liberalism can be seen in conservative and communitarian politics, though even these forces are held in check by the Bill of Rights. (Thus, in a recent documentary program on Plato's Republic made for the Discovery Channel. William Bennett said that Plato had some very good ideas about the promotion of virtue and the control of art-but then immediately said that of course we think that Plato went too far!) Economic libertarians and their opponents (often called "liberals") are, in terms of my argument, rival heirs of the liberal tradition, who differ about how equal respect and liberty should be embodied in laws and institutions. Things are confused by the fact that the Republican party houses both libertarians and anti-liberals. The Democratic party used to contiin many socialist anti-liberals, and still contains numerous communitarian critics of liberalism.

16. Jaggar. p. 29. 
17. Jaggar, p. 30 .

18. Jaggar, p. 40.

19. Jaggar, p. 41.

20. This would seem to be the meaning of the claim that "the egoistic model of humam nature" is unable to admit "(be values of community" (45).

21. Jaggar appears to grant this in the case of Rawls (p. 31), but she insists, nonetheless, that the psychological egoism inherent in liberal theory has left its deforming marks on Rawls's normative theory.

22. Amartya Sen, "Rational Fools: A Critique of the Behavioural Foundations of liconomic Theory," in Choice, Welfare, and Measurement (Oxford: Basil Blackwell, 1982), 84108, discussed in Jaggar p. 45.

23. See Jaggar, $31 \mathrm{ff}$.

24. Although one probably should not count Hobbes as a part of the liberal tradition.

25. Nor is it correct to think that the liberal conception of "happiness" is simply identical to the satisfaction of self-interested desire; there would appear to be no major liberal theorist, with the possible exception of lsentham, of whom that is unqualifiedly true, and in the Kantian tradition there is no tendency at all in this direction.

26. On these arguments, see my The Therafy of Desire: Theory and Prartice in Hellenistic Ethics (Princeton: Princeton University Press, 1994), especially chs. 11-13.

27. I visited SEWA on March 15 and 16, 1997, and base these observations on conversations with Ela Bhatt, Martha Chen, and other members of Uhe organization.

28. See Mill, On Liberty, p. , where he spenks of the importance of overcoming people's lackof interest in the world and getting them engaged in life.

29. We may remark that ancient proponents of self-sulficiency favored masturbation as a way of minimizing dependency on others-see Diogenes Laertius' Life of Diogenes the Cynic. No modern liberal thinker follows this view.

30. In these remarks about Buddhism I am much indebted to conversation with Paul Griffiths.

31. Thus I find quite puzzling Jaggar's claim that liberalism rejects human embodiment ( $p$ p. 31, 40-42). One might, of course, have a metaphysic of separate substances without making embodiment central to it, but then it would be rlifficult to explain why liberalism would devote so much attention to the feeding of those substances.

32. Putting things in terms of happiness and misery should not be taken to suggest either that liberalism is not critical of existing preferences and desires or that the liberal emphasis on separateness requires Pare to optimality for all policies. It might well be that we will allow a larger amount of happiness for $Q$ to compensate for a larger amount of misery for $X$, if we judge that $X$ 's self-generated taste for luxury and power is at the root of his misery.

33. See Jean Drèze and Amartya Sen, Hunger and Public drtion (Oxford: Clarendon Press, 1989). The figure is arrived at by taking as the base line the sex ratio in SubSaharan Africa (where there is great poverty but little evidence of sex discrimination in basic issues of health and mortality), and asking, How many more women than are now in country $C$ would be there if they had the same sex ration as Sub-Saharan Africa?

34. For statistics, see the Human Drvelopment Report 1995, United Nations Development Program.

35. See Nahid Toubia. Female Cenital Mutilation (Second edition, UNICEF, New York. 1995).

36. For these two statistics, and many others, see The World's Women 1970-1990: Trends and Statistics (New York: United Nations, 1991), 19-22.

37. Sec Lori L. Heise, "Freedom Close to Home: The Impact of Violence Against W'omen on Reproductive Rights," in WRHR, 238-55, citing M1. Isabel Rosas. "Violencia Sexual y Politica Criminal, "CI ADEM Informativo No. 6, Lima, April 1992, and Tatianat Treguear I. and Carmen Carro B., Ninas Madres: Rectiento de una Experiencia (San Jose, Costa Rica: PROCAL, 1991), and Flizabeth Shrader-(ox, "Violence Against Women in 
Central America and its Impact on Reproductive Health," paper presented at the Safe Motherhood Central America Conference, Guatemala City, January 27-31, 1992. One should note that women in these societies are not secluded, so the high proportion in the Costa Rican example is significant.

38. See for example Heise, 243-44; most US jurisdictions still require a greater showing of force to convict of rape within marriage, and treat it as a lesser offense, if they do not exempt it completely.

39. If Jaggar had considered that a major alternative to liberal individualism, in worldmetaphysical terms, is the Buddhist denial of the self, would she have spoken so slightingly of individualism?

40. J. S. Mill, The Subjection of Women, ed. S. M. Okin (Indianapolis: Hackett, 1988), p. 33.

41. His reference to Uncle Tom's Cabin in this passage makes it clear that he is thinking about America, and yet he appears to be ignorant of the sexual situation of American slaves.

42. Pp. 33-34. Mill here discusses the Infant Custody Act of 1839 , which allowed the Court of Chancery to award mothers custody of children under the age of seven and access to those under the age of sixteen; this small beginning shows graphically how bad the legal situation of mothers was previously.

43. Pp. 86-88. Compare Considerations on Republican Covernment, where Mill observes that a man who takes no pleasure in his wife's pleasure is "stunted."

44. P. 86.

45. See Theon of Justice $128 \mathrm{f}$. The focus here is on intergenerational justice, and the issue of distribution to the current members of the household is not raised. On p. 463, Rawls states that in a "broader inquiry" the institution of the family "might be questioned, and other arrangements might indeed prove to be preferable."

46. Sec Susan Moller Okin, Women in Westem Political Thought (Princeton: Princeton University Press, 1979, p. 282, on the way in which Mill's proposals showed the limitations of previous liberal individualism.

47. See Amartya Sen, "Gender and Cooperative Conflicts," in Persistent Inequalities, ed. I. Tinker (New York: Oxford University Press, 1990), 123-49.

48. Rawls supports reforms in the divorce law on grounds of sex equality in The Idea of Public Reason," University of Chicago Law Reriew forthcoming.

49. For one impressive critique of the US tax system's inequities toward women, and a proposal for reform, see Edward McCaftery, Taxing Women (Chicago: University of Chicago Press, 1997 forthcoming). McCaffery is a political liberal in the Rawlsian tradition: sec, for example, his "The Political Liberal Case Against the Estate Tax," Philosophy and Public Affairs 23 (1994) 281-312.

50. See Verma, "Femininity," in WCD, p. 441.

51. Rawls, $A$ Theon;, p. 7.

52. Okin, p. 97. She does not, however, address the issue that is really central to Rawls in the context, namely the question whether the parties would represent continuing transgenerational lines or simply themselves. Sec $A$ Theory p. 146, $284 \mathrm{fr}$.

53. S. M. Okin, Justice, Gender, and the Family (New York: Basic Books, 1989). The proposal to make the basic structure of society non-gendered does not, of course, imply that gender might not continue to play a role in the private lives of individuals, much in the way that ethnicity or culture could play a role. Among concrete issues, Okin is particularly concerned with the situation of women in the event of divorce; she urges that women who have done housework to facilitate a spouse's career development should be entitled w a substantial share of his income.

54. J. Rawls, "Gender and the Family," draft; see also "The Idea of Public Reason." Rawls says that it was always his intention that the parties in the original position do not know the sex of those they represent; he points $(1)$ p. 99 , where he says that distinctions of sex are like distinctions of race and culture: they are based on "fixed natural characteristics" and they often influence people's life chances from the very start. 
It should be clear, he says, that the Veil of Ignorance is designed to ensure the parties' ignorance of all features that have this character. Sex (unlike gender, which is a social and institutional category) is a place in the distribution of natural endowments and abilities. (See also "Fairness to Goodness," Philosophisal Ravinw 84 (1975) 537, where Rawls states that the parties do not know their sex.) He also states in Theory, and reaffirms in "The Idea of Public Reason", that the family is certainly a part of the basic strucutre of society, to be constrained by the principles of justice. These will ensure that women who, for religious or other reasons, wish to choose a tradlitional role are free to do so; nonetheless, political principles impose constraints on the fanily as an institution to guarantee the basic rights, liberties, and fair opportunities of all its members. There remains a difference between Rawls and Okin,in that Okin would seem to insist that the internal workings of the fannily should be governed by principles of justice, whereas Rawls envisages the principles of justice operating as constraints on what families may choose, but not as governing its internal workings. The extent to which this is a serious difference needs further examination; it is likely to make most difference where the futures of children are concerned. Rawis continues to work on this topic.

55. Bunch, "Women's Rights as Human Rights: 'Towarcl a Rc-Vision of Human Rights," Human Rights Quarlerly 12: 486-498; sec also Bunch, "liansforming Human Rights from a Feminist Perspective," in WRHR . 11-17, and Elisabeth Friedman, "Women's Human Rights: The Emergence of a Movemem," in WRHR 18-t5.

56. Described in Sara Hossein, "Women's Rights and Personal laws in South Asia," in Human Rights of Women: National and memational P'erspectives (hereafier HRW), ed. Rebecca Cook (Philadelphia: University of Pennsylvania l'ress, 1994) pp. 465-94.

57. See Martha Chen, A Quiet Revolution: Women in Transition in Rurat Banghadesh (Cambridge, MA: Schenkman, 1983).

58. Mill notes that when a opinion is grounded in reason, a good counter-argument will shake its solidity; when it is grounded in irrational desires and fears, good counterarguments merely intensify the resistance: "the worse it fares in argumentative contest, the more persuaded its adherents are that their fecling must have some deeper ground, which the arguments do not reach; and while the fecling remains, it is always throwing up fresh intrenchments of argument to repair any breach made in the old" (pp. 1-2).

59. See Mackinnon, Toutard a Feminist Theon of the State (Cambridge, MA: Harrard University Press, 1989), pp. 40 f.; "Reflections on Sex Equality Under Law," Yale Law Joumal 100 (1991) 1281-1328; Jaggar, Feminist Politics 181 ff. (noting that liberal feminists have been gradually led to abandon the excessively formal approach.

60. Toward Neutral Principles of Constitutional Law," Harrard Law Review 73 (1959). I discuss Wechsler's argument in detail in Potic Justire: The Literan Imagination and Public Life (Boston: Beacon Press, 1996), ch. 4.

61. May Jane Carr v. Allison Gas Turbine Division, (ieneral Mofors Corporation, 32 F. 3d 1007 (7th Cir. 1994). See my Poetic Justice, chapter 4.

62. To some extent, these criticisms are probalbly inspired by the similar criticism of liberalism made by Marx, for example in Critique of the (sotha Program, where Marx argues that the liberal idea of "equal rights" is "constanly stigmitlised by a bourgeois limitation," namely, the neglect of the antecedent role of differences of class and wealth in affecting the productivity of individuals. "It is, therefore, a right of inequality , in its content, like every right... To avoid all these defects, right instead of being equal would have to be unequal." Mackinnon's critique in Tonard a feminist Theory is explicitly inspired by the Marxian critique.

63. Reference to book edited from column.

64. This is not to deny that individual liberal thinkers have made such commitments; and here the libertarian tradition could justly be suspected of having departed from the main line of the liberal tradition, with its strong emphasis on the critique of hierarchies and of the social ascendancy of morally irrelevant distinctions. 
65. For this view, in a feminist context, see Sen, "Gender Inequality and Theories of Justice," and Nussbaum, "Human Capabilities, Female Human Beings," in WCD, pp. $259-73$ and $61-104$.

66. For another type of "perfectionist liberalistn," see Joseph Riv., The Mforality of Free dom (Oxford: Clarendon Press, 1986).

67. This is brought out by Sen in "Freedoms and Needs," The Nro Republic, January 10/17. 1994, and by me in "The Good as Discipline, the Goot as Freedom," forthcoming in D. Crocker, ed. Consumption and Global Sientardship, Rowman and Litulefield, forthcoming 1998.

68. See $A$ Theory of Justice pp. $73 \mathrm{fr}$.

69. T. Sareetha v. T. Venkata Subbaiah, AIR 1983 Andhra Pratesh 356.

70. The case nas angued primarily as a privacy case; but there was a sulbsidiany argument that the Hindu Marriage Act violates equal protection.

71. Not all-see the discussion of Hoff Sommers in chapter 5.

72. For the roles that the imagination should play in developing a liberal theory of the public sphere, see my Poetic Justice.

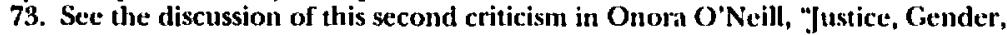
and International Boundaries," in M. Nussbaum and A. Sen, eds., The Qunlity of life (Oxford: Clarendon Press, 1993), 279-323. The feminists criticized by $\mathrm{O}^{\prime}$ Neill include Carol Gilligan, Eva Kittay, Genevieve Lloyd, Sara Ruddlick, and Nel Noddings.

74. This point was well made by Marx in On the Jnvish Question, where-responding 10 Bauer's contention that a person could not qua Jew acquire "the rights of man"he replies that" $[t]$ he incompability between religion and the rights of man is so little manifest in the concept of the rights of man that the right to be religious, in one's own fashion, and to practise one's own particular religion, is expressly included among the rights of man. The privilege of faith is a universal right of man." Unfortunately. Marx (apparently neglecting this insight) goes on to claim that the "rights of man" treat the individual as purely self-centered, "separated from the community, withdrawn into himself, wholly preoccupied with his private interest and acting in accordance with his private caprice." This mistaken claim has probably influenced some feminist critiques.

75. Or, in the case of Rawls, to talents and propensities not integrally bound up with basic rational humanity.

76. See, for example, Rawls, Theor;, p. 207: "to gamble in this way [viz., by allowing the public realm to restrict the liberiy of conscience] would show that one did not take one's religious or moral convictions seriously, or highly value the liberty to examine one's beliefs."

77. For a mordant account of those traditions in their relation to feminism, see Venna in WC.D.

78. Maistre ridiculed liberalism by saying that "there is no such thing as man in the world. I have seen, during my life, Frenchmen, Italians, Russians, eic.... But as far as mon is concerned, I declare that I have never in my life met him; if he exists, he is unknown to me" (cited in Stephen Holmes, The Anatomy of Antilibralism (Cambridge, MA: Harvard University Press, 1993), p. 14. Notice, however, that Maistre is perfectly happy to use high-level abstractions such as "Frenchman," which is, one could argue, far less likely than is "human being" to reveal a set of common features similar across all cases. Compare Mackinnon, "From Practice to theory, or What is a White Women Anyway?". Yale joumal of Law and Feminism 4 (1991) 18-22, who criticizes anti-essentialist feminists for using race and class as legitimate categories while relusing the siune legitimacy to gender.

79. See Friedman, in "Feminism and Modern Friendship," (above).

80. Mackinnon's own degree of "essentialism" about the situation of women has come under sharp attack from communitarian and posimodernist feminists: see the discussion in Elizabeth Rappaport, "Generalizing Gender: Reason and Essence in the l.egal Thoughe of Catharine Mackinnon," in A Mind of One's Oum, pp. 127-44, strongly supporting Mackinnon's essentialism; and see Mackinnon, "What is a White Woman 
Anyway?", criticizing Flizabeth Spelman's Inessential Woman. In her article "Feminist Metaphysics," in A Mind of One's Oum, 273-88, Charlotte Witt argues, plausibly, that Mackjnnon needs, and relies on, an idea of the human being, not just an ideat of woman. For an excellent discussion of the eutire topic, see Charlotte Witt, "Anti-Fssentialism in Feminist Theory," forthcoming in Philosophical Topies (1996).

81. Onora $O^{\prime}$ Neill, "Justice, Gender, and International Boundaries." The articleconstructs an illuminating parallel between the gender boundary and culural/national boundaries. On gender "essentialism," see also C. Mackinnon, "What is a White Woman Anyway?"; and Susan Moller Okin, "Inequalities Between the Sexes in Different Cultural Contexts," in WCD, 27497.

82. Sec also Nussbaum, "Human Capabilities, Female Human Beings," in WCD, $360-95$.

83. Jaggar, Feminist Politirs, p. 28.

84. On Astell, see Margaret Athertom, in A Mind of One's Oun: Feminist Essays on Reason and Objectivity, ed. L. Antony and C. Witt (Boulder, CO: Westview Press, 1993). Aste:ll's major works are now reprinted in... On Musonius, sec Cora Lutz, Yale Classiral Studies; and Nussbaum, The Theraty of Desire: Theory and Praclice in Hellenistir Ehirs (Princeton: Princeton Unjversity Press, 1994), ch. 9; on Greek Stoic attitudes to the equality of women, see Malcolm Schofield, The Stoic ldea of the Cily (Cambridge: Cambridge: University Press, 1991).

85. See Nussbaum, "Emotions and Women's Capabilities," in WCD; also Antuc Fausto-Sterling, Myths of Gender (New York: Basic Books, second cdition 1992).

86. Some examples include Carol Gilligan, In a Different Voice (Cambridge, MA: Harvard University Press, 1982): Nancy Chodorow, The Reproduction of Mothering (Berkeley: University of California Press, 1978); Sara Kuddlick, Matemal Thinking: Tounard a Politics of Peace (Boston: Beacon Press, 1989); Virginia Held, Feminist Morality: Transforming Cullure, Society, and Politics (Chicago: University of Chicago Press, 1993).

87. For criticisms of the reason-emotion contrast, see Martha Minow and Elizabeth Spelman, "Passions Within Reason," Cordozo law Rrview; M. Nussbaum, Poetic Justice: The Literany Imagination and Public Life (Boston: Beacon Press, 1995).

88. See, for example, Catherine I.utr, Unnatural tmotions: Everyday Semtiments on a Micronesian Atoll and their Challenge to Westem Theon (Chicago: University of Chicago Press, 1988); Helen Longino, "To See Feelingly: Reason, Passion, and Dialingue in Feminist Philosophy," in Feminisms in the Academy, ed. D. Stanton and A. Stewart (Ann Arbor: University of Michigan Press, 1995), 19-45.

89. This is the theme of my Gifford Lectures at the University of Edinburgh 1993. forthcoming as Uphenvals of Thought: A Theon of the Emotions (Cambridge: Cambridge University Press, 1993). See also D. Kahan and M. Nussbaum, "Two Conceptions of Emotions in Criminal Law," Columbia Law Review 1996.

90. See Genevieve Lloyd, The Man of Reason; Lutz, Unnatural Emotions, I.ongino, "Tos See Feelingly."

91. Annette Baier, "Hume: The Reflective Woman's Epistemologist," in A Mind of One's Orom.

92. For a trenchant critique that has not been displaced, see Anthony Kenny, in drtion, Emotion, and Will (London 1963), pp. I ff.

93. See Longino, in Sumner and Stanton, summarizing the positions of Lloyd and others. A prominent source of this position within feminism is the psychoanalytical work of Nancy Chodorow, in The Reproduction of Mothering.

94. Nel Nerddings, Caring: A Feminine Approach to Eishics and Moral Education (Berkeley: University of Galifornia Press, 1984). I do not discuss the even more influential views of Carol Gilligan, since it is very unclear what Gilligan's normative view is, and also what analysis she gives to emotions of love and care (to what extent she connects them with thought).

95. Noddings's general position is that the notions of "justificaiton, fairness. justice" are "the language of the father", and that the primary defect in contempo- 
rary ethical thought is that it focuses on this voice rather than on the "mother's voice" (p. 1, etc.).

96. A fruitful comparison would be to the more extensive assault on liberal reciprocity in the work of Emmanuel Levinas. Noddings herself does not discuss Levinas, but she does connect her idea to Martin Buber's account of the I-Thou relation (142).

97. Noddings, p. 137. This forms part of Noddings's argument against Sartre's claim that emotion always has an intentional object.

98. Perhaps I am handicapped by the fact that I simply do not recognize my own experience of motherhood in Noddings's descriptions of fusing and bonding. My first sharp impression of Rachel Nussbaum was as a pair of feet drumming on my diaphragm with a certain distinct separateness, a pair of arms flexing their muscles against my bladder. Before even her hair got into the world a separate voice could be heard inside, proclaiming its individuality or even individualism, and it has not stopped arguing yet, 24 years later. I am sure RN would be quite outraged by the suggestion that her own well being was at any time merged with that of her mother, and her mother would never dare to make such an overweening suggestion. This liberal experience of maternity as the give and take of argument has equipped me ill to understand the larger mysteries of Noddings's text.

99. See the acute criticism of Noddings in Diana Fritz Cates, Compassion for Friends in Fellowship with Gad (Notre Dame: Notre Dame University Press, forthcoming 1997).

100. Nietzsche, Thus Spoke Zarathustra, Part I, "On the Teachers of Virtue". (Kaufmann translates "einnicken" as "drop off", but I have substituted a more literal rendering.)

101. This is Bernard Williams's phrase ("Persons, Character, and Morality," in Moral Luck: Philasophical Papers 1973-80 [Cambridge: Cambridge University Press 1981] p. 18), used in criticism of impartialist views of responsibility that would urge us to reflect on whether we may or may not give special privileges to our own family. Williams says that if a man on a raft, knowing that he can save either his wife or a stranger, but not both, pauses to deliberate at all, he is having "one thought too many." I am not making any claim here about that particular case (Williams may be correct, though it's not obvious that no thought at all should be given to the choice), but it seems likely that a communitarian might say something similar about cases of female self-sacrifice for family, and there I would wish to insist on the relevance of reason, given the social deformation of the norms in question.

102. V. Das and R. Nicholas, "Welfare' and 'Well-Being' in South Asian Societies," ACLSSSRC Jount Committee on South Asia (New York: Social Science Research Council, 1981).

103. See also Marcia Homiak, "Feminism and Aristotle's Rational Ideal," in A Mind of One's Own, 1-17; Jean Hampton, "Feminist Contractarianism," ibid., 227-55; Susan Okin, "Reason and Feeling in Thinking about Justice," Ethics 99 (1989), 229-49.

104. See Mackinnon, Feminism Unmodified (Cambridge, MA: Harvard University Press, 1987); Andrea Dworkin, Inteccourse (New York: The Free Press, 1988).

105. See, for example, Amartya sen, "Gender Inequality and Theories of Justice" in WDC, and also his "Gender and Cooperative Conflicts" (above); J. Elster, Sour Gropes (Cambridge: Cambridge University Press, 1983); John C. Harsanyi, "Morality and the Theory of Rational Behavior," in Utilitarianism and Beyond, ed. A. Sen and B. Williams (Cambrige: Cambridge University Press, 1982), 39-62.

106. J.J. Rousseau, Emile, Book IV.

107. Adam Smith, The Theory of Moral Sentiments (reprinted Liberty Press, 1976), Parts I and III. The remarks especially critical of greed and competition are primarily from the later editions. On Smith's changing attitudes to acquisitiveness, see Ian Simpson Ross, The Life of Adam Sinith (Oxford: Clarendon Press, 1995).

108. This is clearer in the case of Rousseau than in that of Smith: sec Joshua Cohen, "The Natural Goodness of Humanity", forthcoming; but Smith is even more pro- 
foundly influenced by Stoicism than is Rousseau, and the primary emphasis in his critique of desire and emotion is placed on distorting social forces.

109. Pp. 22-3: the judgment of naturalness is said by Mill to be made "with that inability to recognise their own work which distinguishes the unanalytic mind"; see also 12: "... was there ever any domination which did not appear natural to those who possessed it?; and 84: "How rarely it is that even men complain of the general order of society; and how much rarer still would such complaint be, if they did not know of any different order existing anywhere else."

110. P. 16.

111. P. 16.

112. Pp. 12-13.

113. Both Rousseau and Smith, for example, seem to hold this, although Rousseau's argument about the naturalness of gender distinctions is notoriously difficult to interpret. See S. M. Okin, Women in Westem Political Thought (Princeton: Princeton Unvicrsity Press, 1979).

114. See my "Objectification," Philosophy and Public Affairs 24 (1995), 249-91; also, Barbara Herman, "Could it Be Worth Thinking With Kant About Sex and Marriage?" in $A$ Mind of One's Own.

115. See my argument in "Objectification".

116. P. 53.

117. See my "Feminists and Philosophy." New York Review of Books, October 20, 1994.

118. Kant, Crilique of Practical Reason, Conclusion. The origin of this passage is probably in Seneca, Moral Epistle 40: see my "Kant and Stoic Cosmopolitanism," forthcoming in the Jourmal of Political Philosophy. 
The following lectures have been published in individual pamphlet form and may be obtained from the Department at a price of $\$ 2.50$ plus $\$ 1.00$ for handling ( $\$ 3.50$ per lecture).

*1961. "The Idea of Man-An Outline of Philosophical Anthropology." By José Ferrater Mora, Professor of Philosophy, Bryn Mawr College:

1962. "Changes in Events and Ghanges in Things." By A. N. Prior, Professor of Philosophy, University of Manchester.

+1963. "Moral Philosophy and the Analysis of Language:" By Richard B. Brandt, Professor of Philosophy, Swarthmore College.

\%1964. "Human Freedom and the Self," By Roderick M. Chisholm, Professor of Philosophy, Brown 1 niversity.

+1965. "Freedom of Mind."

By Stuart Hampshire, Professor of Philosophy, Princeton University:

"71966. "Some Beliefs about Justice."

By William K. Frankena, Professor of Philosophy, University of Michigan.

+1967. Form and Content in Ethical Theory."

By Wilfrid Sellars, Professor of Philasophy, University of Pitusburgh.

+1968. "The Systematic Unity of Value."

By J. N. Findlay, Clark Professor of Philosophy, Yale University.

1969. "Buber and Buberism - A Gritical Evaluation."

By Paul Edwards, Professor of Philosophy, Brooklyn College of the City University of New York.

1971. "What Actually Happened,"

By P. H. Nowell-Smith, Professor of Philosophy, York University.

†1972. "Moral Rationality."

By Alan Gewirth, Professor of Philosophy, University of Chicago.

+1973. "Reflections on Evil."

By Albert Hofstadter, Professor of Philosophy, University of California, Santa Cruz

+1974. "What is Dialectical?"

By Paul Ricoeur, Professor of Philosophy, University of Paris and University of Chicago.

H1975. "Some Confusions About Subjectivity."

By R. M. Hare, White's Professor of Moral Philosophy at Oxford University and Fellow of Corpus Christi College.

1976. "Self-Defense and Rights."

By fudith Jarvis Thomson. Professor of Philosophy, Massachuseus Institute of Techinology.

1977. "What is Humanism?"

By Georg Henrik von Wright, Research Professor of Philosophy, The Academy of Finland.

1978. "Moral Relativism."

By Philippa Foot, Senior Research Fellow, Somerville College, Oxford; and Professor of Philosophy, University of California, Los Angeles.

1979. "The Idea of the Obscene,"

By Joel Feinberg, Professor of Philosophy, University of Arizona.

1980. "Goods Beyond Price and Other Apparent Anachronisms."

By Warner Wick, Professor of Philosophy, University of Chicago.

1981. "Mondity, Property and Slavery."

By Alan Donagan, Professor of Philosophy, University of Chicago.

- Panphlet out af print.

(continued, back cover)

t Reprinted in Findabs and Marabih.

ff Printed onh in Fimlen and Wovalio: 
1982. "Expressing Evahuations,"

By Donald Davidson. Professor of Philosophy, University of California, Berkeley.

1983. "How Not to Solve Ethical Problems."

By Hilary Putnam, Professor of Philosophy, Harvard University.

1984. Ts Patriotism a Virtue?"

By Alasdair Maclntyre, W. Atton Jones Professor of Philosophy, Vanderbilt University.

1985. "How Free Does the Will Need to Be?"

By Bernard Williams. Provost of King's College Cambridge.

1986. "Moral Agent and Impartial Spectator."

By Gilbert Harman, Professor of Philosophy, Princeton University.

1987. "Projection and Truth in Ethics."

By John McDowell, Professor of Philosophy, University of Piusburgh.

1988. "The Politics of Imagination."

By Arthur Danto, Professor of Philosophy, Columbia University.

1989. "Constituting Democracy."

By David Gauthier, Distinguished Service Professor of Philosophy, University of Pittsburgh.

1990. "Justice and the Good Life."

By Ronald Dworkin, Professor of Jurisprudence, Oxford University, New York University Law School.

1991. "Equality or Priority?"

By Derek Parfit, Professor of Philosophy, All Souls College, Oxford, Harvard University.

1992. "Objectivity and Position."

By Amartya Sen, Lamont University Professor and Professor of

Economics and Philosophy, Harvard Eniversity.

1994. "Families, Nations, and Strangers,"

By Samuel Scheffler, Professor of Philosophy, University of California, Berkeley.

1995. "Wiugenstein on Practice and the Myth of the Giving."

By Susan Hurley, Professor of Political and Ethical Theory, University of Warwick.

1996. "The Diversity of Objections to Inequality."

By T. M. Scanlon, Alford Professor of Natural Refigion, Moral Philosophy, and Civil Polity, Harvard University. 